Universidade de Brasília

Centro de Excelência em Turismo

\title{
CLASSIFICAÇÃO DOS MEIOS DE HOSPEDAGEM
}

Débora Lorenzoni Candeia

Guilherme Vivacqua

Monografia apresentada ao Centro de Excelência em Turismo da

Universidade de Brasília como requisito parcial para a obtenção do certificado de Especialista em Gestão da Hospitalidade 
UNIVERSIDADE DE BRASILIA

Centro de Excelência em Turismo

Curso de Especialização em Gestão da Hospitalidade

\section{CLASSIFICAÇÃO DOS MEIOS DE HOSPEDAGEM}

Débora Lorenzoni Candeia

Banca Examinadora

Guilherme Vivaqcua

Orientador

Membro de Banca

Brasília, DF, 26 de Janeiro de 2004 


\title{
CLASSIFICAÇÃO DOS MEIOS DE HOSPEDAGEM
}

\author{
DÉBORA LORENZONI CANDEIA
}

Comissão Avaliadora

Guilherme Vivaqcua

Professor Orientador

\begin{tabular}{c}
\hline Professor \\
\\
\hline Professor
\end{tabular}

Brasília, DF, 26 de janeiro de 2004 
Candeia, Débora Lorenzoni

Classificação dos Meios de Hospedagem: a validade para os empreendimentos/Débora Candeia.

$71 \mathrm{f}$.

Monografia (especialização) - Universidade de Brasília. Centro de Excelência em Turismo. Brasília, 2003.

Área de concentração: Hotelaria

Orientador: Guilerme Vivacqua.

1. Hotelaria 2.Classificação 3. Meios de Hospedagem 
À meus pais que investiram em meus conhecimentos e ao meu namorado que é referencial de compreensão e de paciência. 


\section{SUMÁRIO}

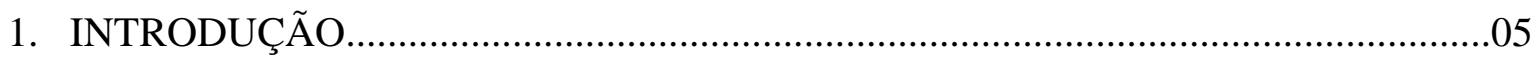

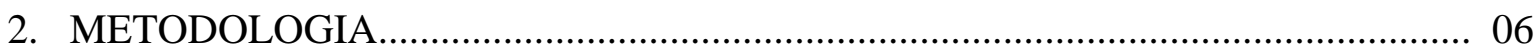

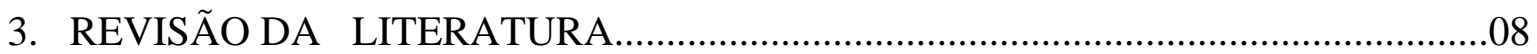

3.1. Origem e Expansão da Hotelaria..........................................................................

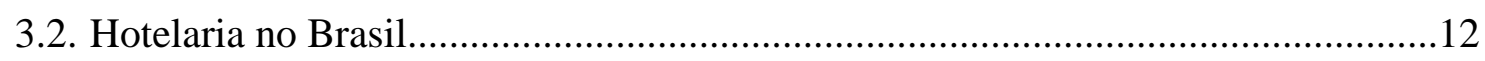

3.3. Excelência em Hotelaria...………………………………………………………….15

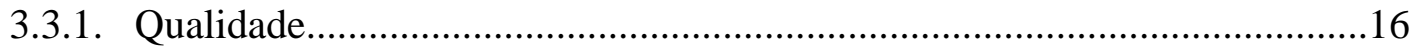

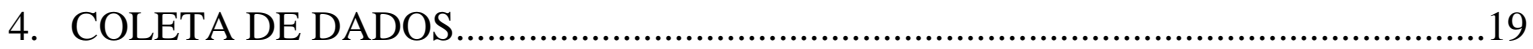

4.1. A Embratur no Contexto da Regulamentação da Classificação dos Meios de Hospedagem................................................................................................19

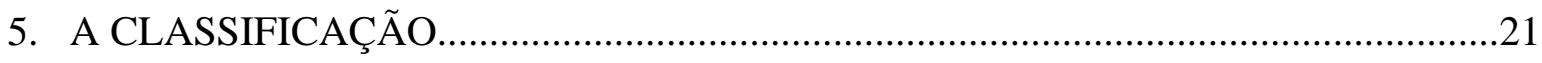

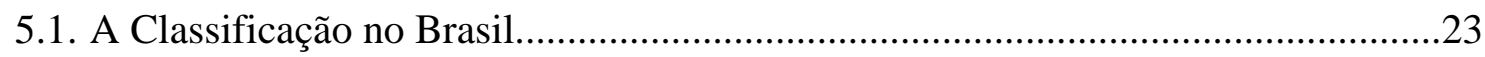

5.2. Os Tipos de Classificações....................................................................................27

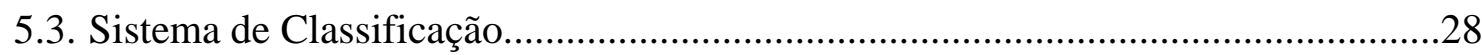

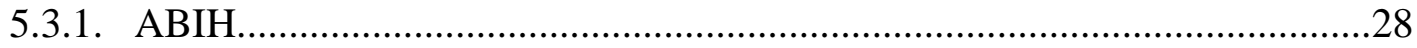

5.3.2. Guia Quatro Rodas....................................................................................

5.3.3. Roteiros de Charme.....................................................................................33

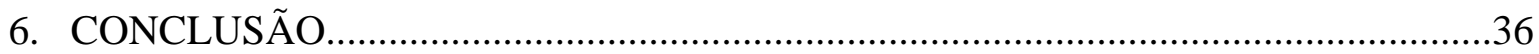

BIBLIOGRAFIA....................................................................................................

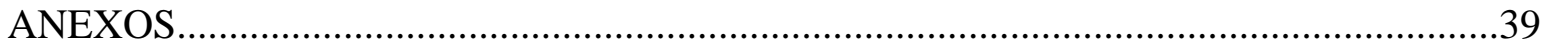

1. Antigo Sistema de Classificação da Embratur.................................................................40

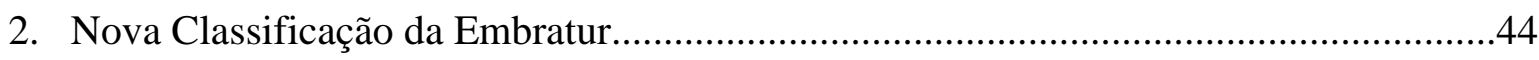

2.1. Deliberação Normativa da Embratur......................................................................4

2.2. Regulamento Geral dos Meios de Hospedagem........................................................46

3. Hotéis Classificados …………………………………...........................................57

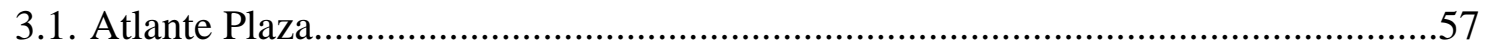

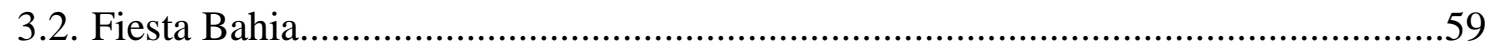

3.3. Pestana Bahia..................................................................................................60

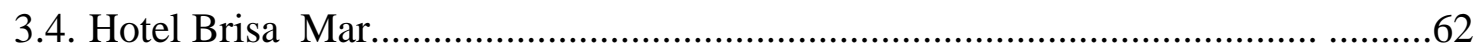

3.5. Hotel Alta Reggia...........................................................................................62

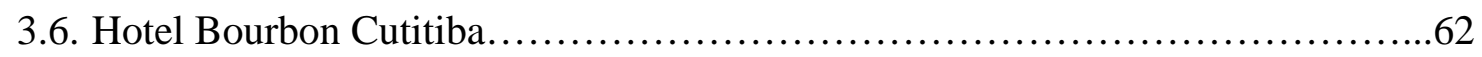

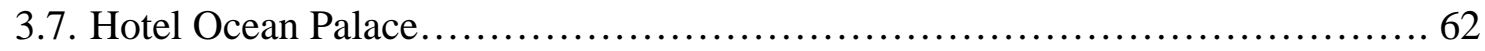




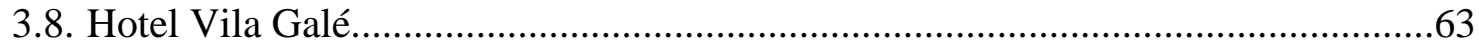

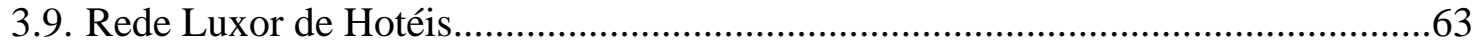

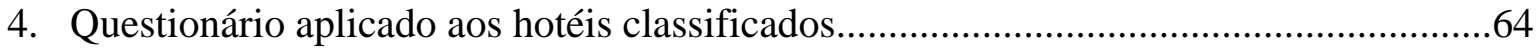

5. Caso Rede Atlantica de Hotéis-Atlantica Hotels International - Comfort Suites Brasilia. 
Resumo

As diferentes categorias de meio de hospedagem hoje são distinguidas fisicamente e operacionalmente pela classificação hoteleira. A classificação é um referencial oficial que tem por objetivo orientar mercados turísticos e empreendedores hoteleiros sobre os padrões a serem executados em seus empreendimentos.

A hipótese central desta pesquisa é avaliar se o Novo regulamento de Sistema Oficial de Classificação de Meios de Hospedagem, deliberado pelo Instituto Brasileiro de Turismo (Embratur) em parceria com a Associação Brasileira da Industria de Hotéis (ABIH), produz realmente benefícios em termos mercadológicos para os empreendimentos que aderirem à nova classificação.

Anteriormente à nova classificação existia uma matriz que não atendia a avaliação de qualidade de serviços prestados, mas somente a infra-estrutura do hotel.

Os meio de hospedagem eram classificados e recebiam estrelas pela infra-estrutura que possuíam e não pela qualidade de serviços prestados, logo se notou que os hotéis de excelente infra-estrutura deixavam a desejar em termos de bons serviços. A grande maioria não se classificava por ter que realizar grandes reformas para se adequar ao que a regulamentação pedia.

A ABIH possuía antes da fusão com a Embratur uma classificação própria, que dividia hoteleiros e empreendimentos e que conseqüentemente dificultava ao consumidor a escolha de um hotel.

Com a grande concorrência hoje nos meios de hospedagem a hotelaria brasileira tem que se adequar aos padrões de exigência cada vez maiores de seus clientes, e alem de sua hospitalidade, qualidade e bons serviços já reconhecidos, têm que mostrar um diferencial, não só de infra-estrutura, mas de serviços.

Uma das formas de mostrar esse diferencial é pela classificação de meios de hospedagem oficial, que além de captar turistas brasileiros possibilitará reconhecimento internacional.

Palavras-chave: meios de hospedagem e sistema de classificação 


\section{INTRODUÇÃO}

As diferentes categorias de meio de hospedagem hoje são distinguidas fisicamente e operacionalmente pela classificação hoteleira. A classificação é um referencial oficial que tem por objetivo orientar mercados turísticos e empreendedores hoteleiros sobre os padrões a serem executados em seus empreendimentos.

Para que a classificação hoteleira se insira num desenvolvimento turístico sustentável, necessita-se dar maior atenção à qualidade de serviços prestados do que somente a infraestrutura do empreendimento.

Partindo daí, é que a pesquisa a seguir tem inicio. Um levantamento e analise dos modelos de certificação dos meios de hospedagem atualmente em vigor no mercado brasileiro.

A pesquisa bibliográfica inicia esse trabalho, abordando evoluções sobre o setor hoteleiro, surgimento das diversas classificações, como são distribuídas, classificações existentes, qualidade na hotelaria, o que o hóspede realmente deseja, qual experiência ele quer ter e que lembrança quer levar consigo. 


\section{METODOLOGIA}

Para a coleta de informações utilizou-se a pesquisa de campo qualitativa, com a analise comparativa e estudo de caso.

Entrevistas foram feitas com responsáveis dos hotéis, Atlante Plaza Recife, um dos poucos classificados pela nova matriz e Comfort Suítes Brasília um dos vários hotéis não classificados, permitindo conhecer a real importância para os empreendimentos da nova matriz na prática.

Essa pesquisa analisará a classificação como referencial de orientação, as várias classificações existentes e a dificuldade para consumidores de distinguirem que classificação ira atender seus anseios, as dificuldades para classificar empreendimentos e as vantagens da classificação.

O problema da pesquisa: a validade da classificação dos meios de hospedagem e sua relevância.

A delimitação do problema de estudo se baseia nas seguintes hipóteses: a classificação não tem êxito em ser um referencial para hoteleiros e consumidores; a matriz é inflexível em vários aspectos não permitindo exceções referentes a peculiaridades de hotéis.

A pesquisa compreende três fases: a escolha da unidade de estudo, a coleta de dados e a analise dos mesmos com interpretação.

As delimitações para a pesquisa são os milhares de empreendimentos não cadastrados, sob nenhuma forma, e que não aparecem legalmente para as estatísticas, bem como os hotéis classificados ficarem localizados em outras cidades que não Brasília, a partir desse fato à de se considerar que Brasília, por exemplo, não contará com nenhum hotel classificado, apenas o Atlante Plaza em recife se propôs a responder a entrevista.

A coleta de dados esta dividida em dois momentos:

1.Coleta de fontes primárias: foram realizadas entrevistas seguindo um roteiro prédeterminado. As entrevistas para hotéis fora de Brasília foram enviadas via e-mail e em Brasília a entrevista com o Comfort Suítes Brasília ocorreu dia 25 de Outubro de 2003. No inicio da entrevista explicava-se o objetivo da pesquisa, somente o dados do Atlante Pçaza Recife foram coletados via questionário pela distancia e impossibilidade da entrevista pessoal. As entrevistas foram complementadas com anotações e com pesquisas a Internet para esclarecimentos de dúvidas referentes aos empreendimentos entrevistados. 
2. Coleta de fontes secundaria: dados recolhidos por intermédio de pesquisas bibliográficas.

O fechamento da pesquisa será a analise e interpretação de dados recolhidos das fontes primaria e secundaria 


\section{REVISÃO DA LITERATURA}

\subsection{Origem e Expansão da Hotelaria}

Ninguém sabe precisar exatamente quando e como surgiu a atividade hoteleira no mundo. Mas, os indícios levam a crer que esta atividade tenha se iniciado em função da necessidade natural que os viajantes têm em procurar abrigo, apoio e alimentação durante suas viagens.De acordo com o livro Introdução a Turismo e Hotelaria, editado pelo SENACServiço Nacional de Aprendizagem Comercial, publicado em 1999, a primeira notícia sobre a criação de um espaço destinado especificamente à hospedagem vem de alguns séculos antes da era cristã, quando na Grécia Antiga, no santuário de Olímpia, eram realizados os jogos olímpicos. Para esses eventos, foram construídos o estádio e o pódio, onde se homenageavam os vencedores e ficava a chama olímpica. Mais tarde, foram acrescentados os balneários e uma hospedaria, com cerca de 10 mil metros quadrados, com o objetivo de abrigar os visitantes. Essa hospedaria teria sido o primeiro hotel que se tem notícia.

Já as termas romanas, embora não se destinassem propriamente à hospedagem e sim ao lazer, dispunham de água quente, instalações de até 100 mil metros quadrados e cômodos para os usuários descansarem.Dependendo do status do cliente, esses aposentos podiam ser luxuosos e de grandes dimensões, ou mais simples, menores, até mesmo de uso coletivo, para as pessoas comuns.

A evolução da hotelaria sofreu grande influência dos gregos e especialmente dos romanos, que tendo sido ótimos construtores de estradas, propiciaram a expansão das viagens por todos os seus domínios e, conseqüentemente, o surgimento de abrigos para os viajantes. A Bretanha, por exemplo, durante muitos séculos dominada por Roma, incorporou à sua cultura a arte de hospedar, e ao longo de suas estradas se multiplicavam as pousadas. Essa mesma tendência era comum a quase todos os países europeus, igualmente influenciados pelos romanos. Como naquela época os meios de transportes não percorriam mais do que 60 quilômetros diários, as viagens quase sempre duravam alguns dias. Disso resultou o estímulo à criação das hospedarias que, em Roma, obedeciam a regras muito rígidas; por exemplo, um hoteleiro não poderia receber um hóspede que não tivesse uma carta assinada por uma autoridade, estivesse ele viajando a negócios ou a serviço do 
imperador.

Nas grandes e refinadas “ mansiones”, amplos "hotéis" situados ao longo das principais vias, tais normas eram seguidas à risca, o que não acontecia nas pequenas pousadas que proliferavam nas redondezas das “mansiones”. Essas hospedarias eram muito numerosas e chegavam a dar nome a certas regiões e a alguns locais de entretenimento, como os circus. A famosa Via Appia, por exemplo, era um local repleto de pequenas pousadas, ao tempo do Império Romano e naqueles estabelecimentos ocorria toda a sorte de orgias, crimes e desordens. Essa época de intrigas políticas e intensa luta pelo poder, os magistrados mantinham essas pousadas sob vigilância, já que civis e militares, além dos funcionários dos correios, ali se hospedavam. Isso levava as autoridades a colocarem os donos de pousada em sua folha de pagamento, para que eles relatassem tudo que ouvissem de seus hóspedes. A lei obrigava a manter vigília à noite, visando à segurança dos hóspedes, de quem era obrigatório anotar os nomes, a procedência e a nacionalidade.Esse panorama continuou mais ou menos inalterado até o final da Idade Antiga. Com a queda do Império Romano, as estradas vieram a ser menos usadas, em razão da falta de segurança. Esse fato diminuiu o número de hóspedes, prejudicando seriamente as pousadas. Desse modo, a hospedagem passou a ser oferecida pelos monastérios e outras instituições religiosas, bem mais seguras e confiáveis.

De início um serviço informal, essa hospitalidade dispensada pelos religiosos tornou-se, mais tarde, uma atividade organizada, com a construção de quartos e refeitórios separados, e monges dedicados ao atendimento dos viajantes. Posteriormente, foram construídos prédios próximos aos monastérios, destinados exclusivamente aos hóspedes dando origem às pousadas. Nesses abrigos, os hóspedes eram obrigados a cuidar da própria alimentação, da iluminação (velas, lampiões, etc) e das roupas de dormir. Além disso, os viajantes dependiam da boa vontade e da acolhida dos responsáveis pelas pousadas.

No século XII, as viagens na Europa voltavam a se tornar mais seguras, e rapidamente as hospedarias se estabeleceram ao longo das estradas. Aos poucos, diversos países implantavam leis e normas para regulamentar a atividade hoteleira, especialmente a França e a Inglaterra. A França, por exemplo, já dispunha de leis reguladoras dos estabelecimentos e dos serviços hoteleiros no ano de 1254 (século XIII), enquanto na Inglaterra isso aconteceu em 1446 (século XV). No ano de 1514 (século XVI), os hoteleiros de Londres foram 
reconhecidos legalmente, passando de hostelers (hospedeiros) para innnholders (hoteleiros). Em 1589, foi editado pelos ingleses o primeiro guia de viagens de que se tem notícia, definindo de modo claro os diferentes tipos de acomodações disponíveis para viajantes a negócio ou passeio. No interior da Inglaterra, muitas pousadas se desenvolveram a partir dos monastérios que fechavam suas portas. Alguns modernos hotéis ingleses, sem dúvida, tiveram essa origem, a exemplo do New Inn, em Gloucester, e o George , em Glastonbury. Em 1650 (século XVII), consolidou-se na Europa um meio de transporte que teve grande influência na expansão da hotelaria: as diligências, carruagens puxadas por cavalos.

Durante quase 200 anos, esses veículos circularam pelas estradas européias, garantindo um fluxo constante de hóspedes para as pousadas e hotéis. Convém notar que muitos serviços de diligências foram estabelecidos pelos próprios hoteleiros, que assim conseguiam assegurar clientela para seus estabelecimentos. Até o fim da era das diligências, em torno do ano de 1840 - quando surgiram as ferrovias -, os terminais de trota e os estábulos ficavam instalados nas pousadas. Velhos estabelecimentos foram reformados ou reconstruídos, outros novos surgiram em estradas que levavam às capitais, devido ao intenso tráfego das diligências. Algumas das maiores pousadas daquele período foram projetadas especificamente para se integrar com esse meio de transporte, fazendo o papel de estação de chegadas e partidas. Dispunham de escritório de reservas e salas de espera; além disso, muitas dessas "estações” possibilitavam ao viajante fazer reservas e comprar passagens de diligências, de várias rotas, a partir da pousada --o Hotel Royal, na Inglaterra, por exemplo, tinha um total de 23 linhas. Com a chegada das ferrovias, as diligências praticamente desapareceram, e a rede hoteleira que delas dependia sofreu um golpe rude, já que as ferrovias eram um meio de transporte muito mais rápido, o que resultava em viagens de menor duração. Muitos hoteleiros não conseguiram se adaptar aos novos tempos, já que estavam habituados com determinadas regras de hospedagem. Dessa maneira, muitos hotéis fecharam suas portas ou reduziram seu tamanho, enquanto outros estabelecimentos conseguiram acompanhar as novas regras e se ambientar com o novo meio de transporte. Novos hotéis foram construídos, próximos às estações ferroviárias, a exemplo de Euston, em Londres.

No final do século XIX., os hóspedes tinham se tornado mais exigentes e surgiram 
então hotéis de grande luxo, como os famosos Savoy, Ritz, Claridge, Carlton e outros, acompanhando a tendência dos fabulosos trens e navios de passageiros da época.

O ano de 1872 trouxe uma novidade: a primeira viagem turística em grupo, organizada por Thomas Cook. 


\subsection{HOTELARIA NO BRASIL}

Segundo Vieira da Luz ( 1999, p.10), no período colonial os viajantes se hospedavam nas casas grandes dos engenhos e fazendas, nos casarões das cidades, nos conventos e, principalmente, nos ranchos que existiam nas beiras das estradas. Erguidas, em geral, pelos proprietários das terras marginais. Eram alpendres construídos às vezes ao lado de estabelecimentos rústicos que forneciam alimentos e bebidas aos viajantes. Aos ranchos e pousadas ao longo das estradas foram se agregando outras atividades comercias e de prestação de serviços que deram origem a povoados e, oportunamente, a cidades. Nessa época era comuns as famílias receberem hospedes em suas casas, havendo em muitas, o quarto de hóspedes.

Movidos pelo dever da caridade, os jesuítas e outras ordens recebiam nos conventos personalidades ilustres e alguns outros hóspedes. No mosteiro de São Bento, no Rio de Janeiro, foi construído, na segunda metade do século XVIII, um edifício exclusivo para hospedaria.

No século XVIII começaram a surgir na cidade do Rio de Janeiro estalagens, ou casa de pastos, que ofereciam alojamento aos interessados, embriões de futuros hotéis. As casas de pasto ofereciam, inicialmente, refeições a preços fixos, mas seus proprietários ampliaram seus negócios e passaram a oferecer também quartos de dormir.

Em 1808, a chegada da corte portuguesa ao Rio de Janeiro e a conseqüente abertura de portos trouxeram um grande fluxo de estrangeiros, que aqui vieram exercer funções diplomáticas, cientificas e comerciais. Com isso, houve aumento da demanda por alojamentos, e no ano seguinte os proprietários da maioria das casas de pensão, hospedarias e tavernas passaram utilizar a denominação de hotel, com intenção de elevar o conceito da casa, independentemente da quantidade de quartos e do padrão dos serviços oferecidos. Cabe destacas, nessa época, o Hotel Pharoux, pela localização estratégica junto ao cais do porto, no largo do Paço, considerado um dos estabelecimentos de maior prestigio no Rio de Janeiro. 
O problema de escassez de hotéis no Rio de Janeiro, que já acontecia em meados do século XIX, prosseguiu no século XX, levando o governo a criar o Decreto №1160 de 23 de dezembro de 1907, que isentava por sete anos, de todos emolumentos e impostos municipais, os cinco primeiros grande hotéis que se instalassem no Rio de Janeiro. Esses hotéis vieram, e com eles o hotel Avenida, o maior de Brasil, inaugurado em 1908. O Avenida, com 220 quartos marca, por assim dizer, a maioridade da hotelaria no Rio De Janeiro.

A partir da década de 30 passaram a ser implantados grandes hotéis nas capitais, nas estâncias minerais e nas áreas de apelo paisagístico, cuja ocupação era promovida pelos cassinos que funcionavam junto aos hotéis. Em 1946, com a proibição dos jogos de azar, os cassinos foram fechados e, como conseqüência, os hoteis a que estavam vinculados acabaram fechando as portas. Exemplos muito conhecidos dessa época são os hotéis Araxá Quitandinha.

Em 1966 é criada a Embratur e, junto com ela, o Fungetur (Fundo Geral de Turismo), que atua através de incentivos fiscais na implantação de hotéis, promovendo uma nova fase na hotelaria brasileira, principalmente no segmento de hotéis de luxo, os chamados cinco estrelas. Esse novo surto hoteleiro levou a mudanças nas leis de zoneamento das grandes capitais, tornando a legislação mais flexível e favorável à construção de hotéis. Nos anos 60 e 70 chegam ao Brasil as redes hoteleiras internacionais. Mesmo sem um número importante de hotéis, essas redes vão criar uma nova orientação na oferta hoteleira, com novos padrões de serviços e preços.

A expansão da hotelaria sob tutela da Embratur, que tem como pano de fundo uma demanda crescente e em grande parte reprimida, teve como conseqüência um desequilíbrio no perfil dos hotéis novos oferecidos, pois a maior parte pertencia à categoria 5 estrelas. Segmentos importantes da demanda, como os ligados a negócios e serviços que buscam hotéis de categoria media econômica, têm sido negligenciados, resultando em uma demanda reprimida ou malservida, a espera de um atendimento mais adequado.

Vieira da Luz ressalta que em São Paulo foram construídos hotéis de menor porte que no Rio, pois os viajantes que permaneciam em São Paulo viajavam a negócios com pouca bagagem, enquanto o Rio recebia turista internacionais, que viajavam durante dias em navios, permanecendo um longo período na cidade e trazendo consigo muitas bagagens que 
eram transportadas em baús; os hotéis então, necessitavam de grandes espaços para guardálas.

A partir dos anos 50 houve um incremento nas viagens, com o desenvolvimento do transporte aéreo, construção de estradas interestaduais e industria automobilística. $\mathrm{Na}$ década de 70 surgiram às primeiras iniciativas do poder publico para incentivo do turismo, as cadeias internacionais começaram a entrar no Brasil devido ao acirramento da concorrência entre essas companhias em nível internacional, a transformação dos pais em um pólo de viagens e à entrada das multinacionais. As cadeias entravam no pais se associando a grupos nacionais que eram responsáveis pelos investimentos imobiliários dos projetos hoteleiros.

Na década de 80 apesar da crise internacional alguns projetos de luxo foram consolidados, mas os hotéis econômicos e intermediários é que marcaram a década de 80. No Brasil iniciaram os flats, dadas as limitações ao financiamento de novos projetos hoteleiros no período.

Nos anos 90 surgiram programas como o PNC - Programa Nordeste Competitivo, em parceria com a Embratur. No entanto até 1994 os projetos foram bastante prejudicados devido à alta inflação e instabilidade econômica, bem como pela estagnação de entrada de estrangeiros, devido ao alto índice de violência principalmente no Ri de Janeiro. Já a partir de 94 com a estabilização do setor o setor sofre uma expansão de demanda promovida pelo incremento da renda da população e financiamento de passagens aéreas e pacotes turísticos. Atualmente, o novo ciclo de investimentos vem reorganizando o setor por intermédio da definição de novos padrões de concorrência e a profissionalização de administração dos empreendimentos.

Segundo a mesma obra, as perspectivas de crescimento da industria hoteleira no Brasil são promissoras, em função da relativa estabilização econômica do país e do aumento acentuado de viagens turísticas nos dois últimos anos, principalmente ao exterior, o que significa que a estabilização da moeda e dos preços conduziu à incorporação do item viagens ao orçamento familiar, pelo menos entre a classe média. 


\subsection{EXCELÊNCIA EM HOTELARIA}

Segundo Castelli ( 1998, p.2) a hotelaria viveu até pouco tempo atrás muito mais um mercado de demanda do que um mercado de oferta. Esta situação gerou uma mentalidade gerencial apática às grandes e rápidas mudanças que estavam ocorrendo no comportamento do consumidor e na nova maneira de gerenciar uma empresa. Hoje existem no país milhares de hotéis, a grande oferta ocorrida nos últimos tempos exige que as empresas hoteleiras recuperem urgentemente o terreno, pois produtos competitivos surgem a cada dia e é preciso ofertar serviços altamente qualificados.

Anteriormente as mudanças ocorriam á níveis de organograma e nunca a níveis de ser humano.

As exigências dos clientes mudam tão velozmente que os empreendimentos não se adaptam a tais mudanças, continuam achando que seu excelente serviço reconhecido anos atrás continuam atuais e satisfatórios atualmente.

Se analisarmos aleatoriamente 50 empresas que faliram, facilmente poderemos identificar a causa: falta de percepção e flexibilidade pelas mudanças. É por meio da qualidade, percebida pelo cliente que a empresa adquire o passaporte que lhe dá permissão de ingressar e de se manter no mercado, podendo assim, melhor competir e assegurar seu futuro. A empresa precisa determinar o seu futuro, saber decidir o que deseja ser para os clientes a que necessidade dos clientes espera atender antes de implantar qualquer técnica.

Pudemos verificar que o cliente que conhece a nova classificação ainda não se adequou e entendeu sua importância. Como a classificação gera custos ao hotel e conseqüentemente um aumento no valor de diárias ou serviços, os hóspedes que freqüentavam determinado hotel com uma determinada tarifa antes da classificação, desistem de freqüenta-lo pois não tem condições financeiras para arcar com os novos valores.

O cliente quer acima de tudo bom atendimento, ele quer ser cuidado e mimado, se para isso ele tiver que optar por um hotel menor e desclassificado que lhe ofereça tal cuidado ele vai com certeza ficar com o menor hotel, pois muitas vezes os hotéis classificados cuidam da infra estrutura e não do pessoal que vai encantar o cliente. 


\subsubsection{QUALIDADE}

Segundo o mesmo autor (1998,p15), num mundo cada vez mais globalizado só terão vez as empresas que oferecerem produtos e serviços com a qualidade exigida pelos clientes. Qualidade é uma atitude, não tem começo, meio ou fim. A qualidade de um produto - e o processo pela qual ela é incorporada aa esse produto - exige uma continuidade e deve chegar a integrar-se à mentalidade de cada funcionário. (Lee Iacocca, 1993).

Segundo Crosby, qualidade e a conformidade com os requisitos, servem para marcar um acordo entre pessoas e devem tomar a forma que seja necessária. Devem ser respeitados e jamais alterados, a não ser por intermédio de acordo entre aqueles que os criaram.

${ }^{1} \mathrm{O}$ hotel precisa oferecer produtos e serviços com qualidade para poder conectar-se a seus clientes. Para tanto, é necessário estabelecer requisitos que traduzam os seus desejos, necessidades e expectativas. Uma vez estabelecidos, cumpri-los a risca, já que a qualidade é a conformidade com os requisitos.

O conjunto ou a soma de todos os requisitos de todas as áreas que compõem a estrutura do hotel vai determinar a sua categoria: 5, 4, 3,2 e 1 estrela. Nesse caso, pode-se então afirmar que um hotel cinco estrelas é de melhor qualidade que um outro de duas? Não, ambos podem ser de excelente qualidade, desde que cumpram os requisitos atinentes a sua categoria. Eles têm categorias distintas, em vista disso conforto e atendimento diferenciados. Uma vez fixados os requisitos, é possível, verificar através de técnicas de medida, sua conformidade ou não com os mesmos. Para bens materiais é fácil medir, o mesmo não acontece com os serviços, devido aos seus componentes imateriais. Isso não quer dizer que não possam ser medidos, pois existem medidas qualitativas.Por exemplo, a rapidez de um serviço pode ser medida. Existe um tempo de espera por um pedido feito por um cliente ao restaurante, ao bar ou room service. Rapidez significa cumprir com o tempo combinado.Se o tempo para atender

${ }^{1}$ CASTELLI,Geraldo. Excelência em Hotelaria. p. 24-46 
a um pedido de restaurante for de 15 minutos, este deve ser cumprido, para que o cliente tenha suas expectativas atendidas. Quantas vezes por dia tal padrão não foi atendido? A resposta vai indicar se a qualidade existe ou não.

O hotel é considerado uma industria pelo fato de transformar matérias primas em produtos acabados e de outro lado como comércio pelo fato de prestar serviços, mas quanto aos serviços temos grandes dificuldades de teorização, isto porque, a qualidade sentida por um cliente quando do fornecimento de um serviço diferencia-se da qualidade de conformidade de um produto manufaturado, por causa da interação direta entre o cliente e o serviço durante a sua prestação.

A qualidade pode ser percebida por seus componentes materiais e imateriais: Componentes materiais são percebidos pela tangibilidade dos produtos, tudo aquilo que o cliente sente e vê, a aparência física interna do hotel, conservação, limpeza, iluminação, sinalização e uniformes.

Os imateriais são formados pelo conjunto de ações que caracterizam a qualidade humana, ou subjetiva do serviço, como amabilidade, cortesia, cooperação. Um exemplo é a cortesia, como materializá-la? Deve haver disposição para servir, um recepcionista pode sorrir par ao cliente sem estar disponível para servi-lo, ele pode sorrir sem nenhuma expressão corporal, sentado atrás do balcão, por exemplo. A qualidade humana é crucial nas prestações hoteleiras, até por que a qualidade dos bens e serviços depende quase por inteiro da atuação das pessoas individualmente ou em grupo.Produtos e serviços de qualidade só podem provir de funcionários com alto nível de qualificação, inseridos num excelente processo. De pouco adianta ter pessoas educadas e qualificadas trabalhando num processo cheio de falhas, a recíproca também é verdadeira. Mesmo com todos esses conceitos devemos saber que a qualidade tem uma dose de subjetividade, a qualidade pode ser percebida de diversas maneiras pelas pessoas ou pela mesma pessoa na dependência de seu estado emocional.

O hotel presta múltiplos e variados serviços durante a estada do hóspede. É muito importante que todos os setores e pessoas neles envolvidas tenham a mesma noção quanto ao conceito de qualidade no fornecimento de bens e serviços. Se um cliente estiver hospedado num hotel cinco estrelas é de pressupor que os diversos serviços prestados estejam dentro do mesmo padrão. O que não pode acontecer são algumas áreas oferecer um 
serviço do tipo cinco estrelas e outras, um de duas. É preciso ter sempre presente a idéia do hotel como sistema e que a satisfação do cliente, é conseqüência de uma resposta positiva de todas as partes que compõem esse sistema, e não apenas de algumas delas.

Não basta somente satisfazer as exigências dos clientes, é preciso fazer melhor que os concorrentes. A empresa precisa olhar para fora, para o futuro, precisa saber se preparar para enfrentar a concorrência. Ela precisa definir suas metas e métodos por meio de seu planejamento estratégico. Através de bens e serviços bons, bonitos, bem feitos e baratos. Isso é um desafio para a empresa.

A empresa deve estar rompendo com práticas gerenciais que não mais conseguem atender às exigências dos clientes. Exigências essas que estão que estão em continua mutação.

Por este motivo a empresa deve estar num processo de melhoria continua, preocupada com seu futuro coma modernização de seus equipamentos, com o desenvolvimento de novos produtos, de tal forma a garantir a satisfação total do cliente. 


\section{COLETA DE DADOS}

4.1.A Embratur no contexto da Regulamentação da Classificação dos Meios de Hospedagem

Embratur $^{1}$ - Empresa Brasileira de Turismo foi criada em 66 para controlar as atividades e os empreendimentos relacionados a turismo no país. Também foi criado um órgão que passou a elaborar as diretrizes políticas para o setor, chamado CNTur - Conselho Nacional de Turismo.

Em 1971, a Embratur passou a gerenciar o Fungetur - Fundo Geral de Turismo, destinados ao financiamento de investimentos no setor.

Em 1975, investiu na mão de obra do setor hoteleiro para estimular o turismo receptivo internacional. Foi nessa época que passou a classificar os empreendimentos hoteleiros como forma de orientar o consumidor.

Em 1977 tornou a classificação obrigatória e estabeleceu limite de valores entre as diferentes categorias de hotéis. No inicio dos anos oitenta estabeleceu regras para o registro. Em 1991, a Embratur se vinculou à Secretaria de Desenvolvimento Regional do Ministério. No ano seguinte passou a ser responsável pela divulgação internacional dos pólos turísticos nacionais.

Em 1997, acabou com o sistema de classificação de hotéis e reorganizou o Fungetur. A partir desse ano a Embratur passou a pertencer ao ministério da Industria, do Comercio e do Turismo ate 2002 pertenceu ao Ministério do Esporte e Turismo e atualmente pertence ao Ministério do Turismo.

A Embratur em 2003 passou a ter um novo foco: o instituto será responsável pela promoção, marketing e apoio a comercialização dos produtos brasileiros no exterior.

Com a criação do Ministério do Turismo a Embratur passou a cuidar exclusivamente da promoção do Brasil no exterior. Durante o lançamento do Plano Nacional de Turismo no dia 29/04/03 o presidente Lula falou da importância que o setor terá no governo dizendo que o Turismo será a atividade marcante.

De acordo com o PNT (Plano Nacional de Turismo) a Embratur ficara responsável por executar nos quatro anos:

\footnotetext{
${ }^{2}$ Fonte: http://www.embratur.gov.br>acesso em 14 out 2003.
} 
A elaboração e a implantação do plano de marketing para o turismo brasileiro;

A definição e execução da política de ações promocionais e apoio à comercialização dos produtos turísticos;

A formatação e organização de novos produtos e roteiros turísticos integrados e;

A elaboração de estudos e pesquisas que orientem os processos de tomada decisão e avaliem o impacto da atividade turística na economia nacional.

A promoção do turismo brasileiro no mercado internacional terá como conceito estratégico a diversificação da imagem no pais. O trabalho de marketing ira orientar a construção do Brasil como conceito turístico moderno, com credibilidade, jovem, hospitaleiro, capaz de proporcionar lazer de qualidade, novas experiências aos visitantes, realizar negócios e ser competitivo internacionalmente. 


\section{A CLASSIFICAÇÃO}

Segundo Cooper (2001, p 363), a classificação pode ser definida como a colocação de hotéis em categorias de acordo com o tipo de propriedade, instalações e amenidades oferecidas, sendo este, o enfoque tradicional na maioria das matrizes. Na pratica, a maioria dos sistemas de classificação, concentram-se na qualidade como um adicional que não tem impacto sobre a concessão de estrelas de um estabelecimento.Normalmente as matrizes de classificação tem por finalidade a padronização para estabelecer uma qualidade uniforme de produtos e serviços; o marketing para assessorar os viajantes sobre os tipos de hospedagem disponíveis; a proteção ao consumidor, para garantir que o empreendimento atenda a padrões mínimos de acomodação, instalações e serviços; a geração de receita, para produzir renda a partir do licenciamento e etc; o controle, para fornecer um sistema de controle geral da qualidade na atividade; incentivos aos investimentos, para dar aos operadores incentivos para melhoramentos em suas instalações. Quem realiza a certificação é um grupo de profissionais especializados na certificação pertencentes à Embratur.

As avaliações feitas pela classificação deveriam ter maior importância para a equipe dos empreendimentos que deviam ver a grande oportunidade de promover melhorias e mudanças nos serviços prestados e no produto oferecido, ao invés de mostrarem ao cliente uma mera classificação. Os empreendimentos pensam muitas vezes apenas na mudança de infra estrutura que vai ocorrer e esquecem da qualidade de serviços.

A classificação não acontece sem problemas. Um deles é a subjetividade do julgamento envolvido na avaliação da maioria dos aspectos relacionados à qualidade e serviços pessoais. Como conseqüência a classificação se concentra nos atributos físicos e quantificáveis das operações, determinando a classe com base em características como o tamanho dos quartos, instalações, a presença ou não de banheiros nos apartamentos e a disponibilidade de serviços. Isso tudo é feito muitas vezes sem a avaliação da qualidade do fornecimento ou a consistência da prestação de serviços.

A qualidade da avaliação esta enraizada na cultura e no contexto do pais no qual estão localizados. Exemplo: um hotel cinco estrelas localizado no Brasil será muito diferente de um empreendimento localizado no Japão, isso quer dizes que uma matriz de classificação pode fornecer um guia de padrões nacionais, Mas, isso não acontece no Brasil.

Outro problema é o de acomodar o conforto físico com a ausência de serviços disponíveis ao hospede. 
Os hotéis econômicos de hoje não são mais hotéis de simples infra-estrutura, eles acomodam confortavelmente os hospedes em grandes espaços, mas continuam com poucos serviços, eles mantem os mesmos serviços de um hotel econômico em instalações maiores. Antes disso hospedes que quisessem hotéis de baixo custo procurariam hotéis de padrão duas ou três estrelas. A classificação se confunde na hora de categorizar hotéis econômicos com instalações tão distintas. 


\subsection{A CLASSIFICAÇÃO NO BRASIL}

De acordo com Vieira da Luz (1999,p.95), a classificação dos meios de hospedagem no Brasil foi instituída em 1978 pelo Conselho Nacional de Turismo (CNTur), com o objetivo de estimular a criação de pacotes internacionais para o País. O sistema de classificação adotado foi o misto (presença/ausência e classificação por pontos) e previa a realização de duas vistorias anuais, realizadas de forma ostensiva e sem aviso prévio. A classificação não era compulsória e dependia de solicitação dos hotéis.

Mas a referida classificação atribuiu, aproximadamente, 70\% dos pontos aos aspectos construtivos, aos equipamentos e às instalações e tão somente $30 \%$ deles aos serviços. Isso contribuiu para que os hotéis se preocupassem mais com a infra-estrutura física, deixando quase que esquecida a prestação dos serviços, ocasionando muita descontentação por parte dos hóspedes, pois para a maioria deles, a prestação de serviços é muito mais importante do que a infra-estrutura. O ideal para os hóspedes é que haja um equilíbrio nas atribuições.

Vários grupos hoteleiros no País opuseram-se à classificação, pois esta norma criaria a distinção entre os turistas que se hospedavam em hotéis de diferentes padrões e constrangeria a maior parte dos hoteleiros, cujos empreendimentos eram modestos.

Para o mesmo autor, a partir de 1978, os meios de hospedagem no Brasil foram segmentados em hotéis (apartamentos privativos e banheiros e/ou salas), hotéis-residência (apartamentos com cozinha), hotéis de lazer (apartamentos privativos, duas dependências, cinco equipamentos e atividades de recreação), pousadas (instalações com valor histórico) e hospedarias de turismo (estabelecimentos simples com banheiros coletivos). Também passaram a ser exigidos padrões mínimos de atendimento, como oferta de café da manhã, limpeza e arrumação diária dos quartos, serviços de portaria vinte e quatro horas entre outros.

O mesmo autor coloca que durante a década de oitenta, o crescimento desordenado do número de hotéis cinco estrelas levou ao descrédito o sistema de classificação da Embratur. Segundo dados do Guia Quatro Rodas, dos 2,4 mil hotéis classificados pela empresa, 104 eram cinco estrelas, mais que o total de hotéis de luxo dos Estados Unidos e França. Este crescimento do número de hotéis cinco estrelas esteve associado ao interesse dos hoteleiros 
em obter a liberação das tarifas, que, na ocasião, era permitida apenas para os empreendimentos com classificação acima de quatro estrelas.

Para restabelecer a credibilidade, segundo o mesmo autor (1198,p.95) do sistema de estrelas, de acordo com a mesma obra, a Embratur procurou, em 1996, desenvolver um processo de reclassificação, em parceria com a Associação Brasileira da Indústria de Hotéis (ABIH). No entanto, a associação e a Embratur não chegaram a um consenso sobre os critérios a serem utilizados para reavaliação. A Embratur contratou então o Instituto Nacional de Metrologia e Qualidade Industrial (Inmetro), que credenciou doze institutos para certificar e reclassificar os hotéis com base nas normas da ISO 9000. Com isso, em fevereiro de 1997, a classificação da Embratur instituída em 1978 foi abolida.

Contudo, conforme o mesmo autor, os novos sistemas de classificação baseados em critérios rígidos e avaliados por equipes independentes não foram aceitos pela maior parte dos hoteleiros, pois o rebaixamento na classificação poderia implicar em perdas de receitas. A maior parte dos hoteleiros também não concordava com o pagamento de cerca de US\$ 6 mil pela certificação, dificultando também, a adesão de hotéis de médio e pequeno porte. Em janeiro de 1998, apenas dezenove dos 2,4 mil hotéis do País haviam adotado a classificação da Embratur. Nessa ocasião, os hotéis que utilizavam o critério de estrelas, sem autorização da Embratur, foram ameaçados de processo por propaganda enganosa.

Até 14 de janeiro de 2002, houve um pequeno aumento de adesões ao sistema de classificação, onde vinte e nove hotéis estavam regularmente classificados pelo sistema oficial, sendo que vinte e três na categoria luxo superior cinco estrelas, três na categoria luxo quatro estrelas e três na categoria standard superior três estrelas.

Diante desta situação de dificuldades enfrentadas pelos meios de hospedagem, como a distinção entre turistas, valores para certificação e medo de perder estrelas, para se classificar pelas normas da Embratur, a ABIH criou, em 1997, um sistema próprio de classificação como uma alternativa ao sistema de classificação da Embratur. Segundo Vieira da Luz, o sistema estabelecia que a categoria do empreendimento, identificada pelo número de asteriscos, fosse definida pelo hoteleiro, com base nos equipamentos e serviços disponíveis. Novamente houve uma preocupação grande com a infra-estrutura e deixando quase que esquecida a qualidade dos serviços prestados.

De acordo com os serviços e equipamentos disponíveis, os hotéis poderiam se autoclassificar nas categorias superluxo, luxo, superior, turístico, econômico e simples. Para esse caso, o conselho de ética da $\mathrm{ABIH}$ seria responsável pela apuração de denúncias e 
aplicação de multa e sansões para os hotéis que não cumprissem os critérios definidos para as categorias.

Como a ABIH institui o sistema de autoclassificação, muitos hotéis burlavam as informações referentes ao seu estabelecimento para conseguir uma melhor classificação, isto é, podendo se classificar em uma categoria a que, realmente, ele não pertencia, para poder conseguir melhor prestígio e rendimentos. Devido ao grande número de hotéis classificados pela ABIH e pela total desorganização e incompetência da associação em fiscalizar e apurar denúncias referentes aos hotéis classificados percebeu-se que muitos poderiam estar burlando as normas.

Devido às observações acima, em novembro de 1999, a procuradoria regional dos direitos do cidadão, no estado de Santa Catarina, recomendou que a ABIH se abstivesse de classificar os hotéis, sob pena de incorrer na prática de ilícito previsto no Código de Defesa do Consumidor, recolhendo ou cancelando quaisquer documentos com tal finalidade no prazo de trinta dias. Em sua recomendação, a procuradoria observa que somente a Embratur tem a competência para cadastrar e classificar os empreendimentos dedicados à atividade turística e ressalta que a classificação por intermédio de critérios estranhos ao órgão gera riscos de confusão ou falsa expectativa aos consumidores, podendo consistir em publicidade enganosa.

Em virtude dessa confusão estabelecida pelas duas formas em que os meios de hospedagem vinham classificando seus estabelecimentos, o Guia Quatro Rodas passou a dar ao consumidor maior segurança por ser considerado a mais tradicional publicação na área de turismo do País, que segundo informações da editora que publica o guia, ele foi criado no início da década de sessenta, por Victor Civita, fundador da Editora Abril, tendo como referência o guia de turismo francês Michelin. O primeiro exemplar, publicado em 1966, relacionava 663 hotéis em 283 cidades brasileiras.

Segundo Vieira da Luz, o objetivo da publicação é oferecer aos leitores um painel das opções turísticas existentes no País e avaliar a qualidade dos serviços oferecidos, com base em critérios jornalísticos bem definidos e ligados aos desejos humanos e simples, como uma cama confortável para dormir, uma boa limpeza do apartamento, diversidade de entretenimento, cortesia dos funcionários, comida diversificada e saborosa, rapidez do room service, atendimento telefônico cortes e eficaz, arrumação do apto feita todos os dias e trocas de toalhas diariamente. Tanto a classificação quanto a avaliação dos serviços e dos estabelecimentos são realizadas a partir de visitas anônimas. 
De acordo com o mesmo autor, a classificação do Guia Quatro Rodas consolidou-se como uma das mais respeitadas no setor hoteleiro, por conta de sua isenção e credibilidade. Entre 1966 e 1995, os estabelecimentos eram classificados em sete categorias, conforme suas características e seu padrão. Nesse período, o número de hotéis relacionados cresceu de 663 para 5,13 mil. Em 1996, o número de categorias foi reduzido para cinco (luxo, muito confortável, confortável, médio conforto e simples). Com isso, o número de estabelecimentos relacionados caiu para 3,95 mil, total 23\% menor que o do ano anterior. Em 1999, o guia relaciona 4,66 mil estabelecimentos, 18\% mais que em 1996. Esse crescimento foi atribuído à expansão do parque hoteleiro nacional nesse período.

O Roteiro de Charme é uma classificação bem mais simples mas muito seguida por seus conhecedores, ela é apenas pouco divulgada e reconhecida por órgãos oficiais. É uma classificação que utiliza pedras preciosas e semi preciosas para categorizar os hotéis por ela classificados.

É importante ressaltar que não existem custos para os hotéis classificados pelo Guia Quatro Rodas, inclusive, todas as despesas de transporte, hospedagem e alimentação dos repórteres são pagas pela editora do guia.

Dispostos a mudar esta dura realidade, no início de 2001, a ABIH e Embratur uniramse para criar um outro modelo de avaliação e classificação.

Este modelo pretende corrigir distorções do passado e é um grande acontecimento para o setor hoteleiro, mas o principal aspecto é que ele permitirá à iniciativa privada e ao poder público trabalharem juntos. Ou seja, o gerenciamento do novo sistema será de responsabilidade compartilhada. A ABIH elaborou a matriz e a entregou à Embratur que fez algumas adequações julgadas necessárias. A matriz enfatiza bastante a qualidade dos serviços. O sistema é basicamente baseado em garantia de qualidade, já que foi inspirado no modelo da ISO 9000. Dessa forma, o primeiro passo para a classificação é que o hotel terá que comprovar que faz o gerenciamento da qualidade. Após a classificação em determinada categoria, anualmente, o estabelecimento passará por uma reavaliação. Esse novo Sistema de Classificação dos Meios de Hospedagem será abordado em sua totalidade no terceiro capítulo. 


\subsection{OS TIPOS DE CLASSIFICAÇÕES}

O Brasil contava com quatro classificações principais para meios de hospedagem.

A ABIH usava um sistema de classificação por asteriscos, mas foi suspensa em 1999, a partir daí a Associação não classificou mais nenhum empreendimento.

O Guia Quatro Rodas, referencia nacional para turistas, tem classificação própria, sempre reformulando conceitos para melhor atender o turista, é considerado o guia mais usado pelos viajantes.

Roteiros de Charme é outra classificação, e utiliza pedras preciosas e semipreciosas para classificar os meios de hospedagem.

A classificação oficial hoje é a da Embratur, que passou por reformulações em parceria com a ABIH entrando em vigor no dia 12 de Julho de 2002, sob competência do Ministério do Turismo.

Atualmente 14 hotéis já tem a nova classificação, são eles: O Fiesta Bahia Hotel e o Hotel Pestana em Salvador; o Hotel Atlante Plaza em Recife; o Marina Park Hotel em Fortaleza; o Brisa Mar Hotel em São Luiz; o Hotel Alta Reggia e o Hotel Bourbon em Curitiba; o Hotel Pestana em Natal , Ocean Palece me Natal, Vila Galé em Fortaleza e Rede Luxor com hotéis em Fortaleza e no Rio de Janeiro. 


\subsection{SISTEMA DE CLASSIFICAÇÃO}

\subsubsection{ABIH}

Devido à situação de dificuldades enfrentadas pelos meios de hospedagem para se classificarem pelas normas da Embratur, a ABIH criou em 1997 um sistema próprio de classificação. O sistema estabelecia que a categoria do empreendimento, identificada pelo número de asteriscos, fosse definida pelo hoteleiro, com base nos equipamentos e serviços disponíveis.

A procuradoria regional dos direitos do cidadão no estado de Santa Catarina recomendou em novembro de 1999 que a ABIH se abstivesse de classificar os hotéis, ressaltando que a classificação praticada pela associação utilizava critérios estranhos, gerando riscos de confusão ou falsa expectativa aos consumidores, podendo consistir publicidade enganosa. Depois desta decisão, a classificação da ABIH ficou suspensa por tempo indeterminado, gerando um grande problema, pois a associação não podia fazer mais nenhuma nova classificação e os hotéis que já possuíam a classificação não puderam mais usufruir as vantagens em estarem classificados.

Como o sistema de classificação da ABIH era de autoclassificação, onde o próprio hoteleiro enquadrava seu hotel em uma das categorias existentes representadas por asteriscos baseados nos equipamentos e serviços disponíveis, houve grande número de hotéis que não atendiam às exigências do sistema e, mesmo assim, mantinham sua classificação. Isto aconteceu devido ao grande número de hotéis classificados e pela falta de fiscalização da associação.

A partir do exposto acima, pode-se dizer que a $\mathrm{ABIH}$, por intermédio de sua metodologia de classificação sempre procurou afrontar a Embratur, classificando o maior número de hotéis por intermédio de suas facilidades de adesão, tanto na questão da autoclassificação quanto na questão dos preços aplicados para classificação, que eram bem inferiores aos praticados pela Embratur. Isto foi muito prejudicial, pois não tinham condições de classificar nenhum meio de hospedagem devido a sua estranha metodologia de classificação, que, como resultado, não fizeram as vistorias e fiscalizações necessárias para poder realmente classificar um hotel. 
Outro aspecto importante a frisar foi a confusão e a falsa expectativa causada nos consumidores quando lançaram seu sistema de classificação. Geraram confusão na questão dos símbolos utilizados (asteriscos), pois a Embratur utiliza estrelas, sendo que muitos dos hotéis, classificados com asteriscos, diziam aos seus hóspedes que eram classificados por estrelas, o que sempre foi marca consagrada não só da Embratur, mas também de sistemas de classificação de vários países. Hóspedes que faziam suas reservas em muitos dos hotéis classificados pela ABIH com a certeza de que estariam se hospedando em um hotel da categoria vendida (tantos asteriscos ou "estrelas"), decepcionavam-se ao serem surpreendidos por um hotel muito inferior, tanto em aspectos de infra-estrutura, quanto aos serviços prestados, em qualquer outro hotel da mesma categoria reservada.

Portanto, a ABIH não foi capaz de classificar os meios de hospedagem com eficiência e seriedade pela qual havia se proposto a fazer, chegando ao extremo de sua classificação ser impedida judicialmente.

Para o novo sistema de classificação, no qual a ABIH está como parceira do Ministério do Turismo, mesmo que todas as etapas tenham sido passadas detalhadamente por técnicos da Embratur, a ABIH com esse seu curto e desastroso histórico em classificar meios de hospedagem, só terá condições de atuar eficientemente neste processo, se houver empenho e seriedade desta associação.

Deve-se ressaltar que, nem todos os hotéis classificados pela ABIH tinham as atitudes citadas acima, sendo que muitos levavam a sério a classificação, respeitando a todas as normas e, principalmente, aos seus hóspedes. 


\subsubsection{GUIA QUATRO RODAS}

O Guia Quatro Rodas ainda é a forma mais utilizada pelo consumidor na escolha do meio de hospedagem que irá utilizar em suas viagens, até porque, ele é de fácil acesso para o consumidor, tanto nas edições que são publicadas e vendidas em qualquer loja do gênero, quanto nas informações disponíveis na Internet.

A metodologia utilizada para se classificar os meios de hospedagem é a seguinte:

O Guia Quatro Rodas utiliza critérios de qualidade para a classificação dos hotéis e restaurantes, os quais são basicamente jornalísticos. É utilizada muita investigação, comparação, enquetes e experimentação. Apesar desse “feeling” que orienta o trabalho, como ocorre nas publicações sérias do gênero, existe um registro técnico, tentando evitar que a subjetividade prejudique a análise dos estabelecimentos.

Anualmente, fazem uma avaliação de cada hotel, levando em conta a sua destinação (executivo, lazer, trânsito, etc), localização, construção, apartamentos, equipamentos, áreas de lazer e social, estrutura e serviços. Para cada item existe uma pontuação (de 1 a 5, 1 a 10, 1 a 15 ou 1 a 20), com escalas diferentes - uma para hotéis convencionais, outra para hotéis de lazer. O objetivo é fornecer ao leitor condições para escolher onde se hospedar de acordo com o seu grau de exigência e conforto.

Sua forma de trabalho serve justamente para evitar qualquer tipo de vício ou apadrinhamento que poderiam ocorrer caso trabalhassem com fontes ou sucursais, tendo sua equipe baseada em São Paulo. Sempre há rodízio nas viagens, que duram entre vinte e cinco e trinta dias, com todas as despesas pagas pela Editora Abril. O repórter viaja sozinho e quando está hospedado ou experimentando algum restaurante, só se identifica após pagar as despesas e pedir nota fiscal. O anonimato e a discrição são características fortes do Guia Quatro Rodas.

Todos os repórteres do Guia Quatro Rodas passam por um processo de treinamento que incluí pesquisas juntamente com os editores de hotéis e de restaurantes, visita a atrações turísticas e a leitura do manual de redação. Após esta parte introdutória, geralmente em cidades como São Paulo e Rio de Janeiro (onde terá melhores parâmetros), ele faz a viagem com algum editor ou repórter mais experiente. 
Existe manifestação dos leitores quanto a critérios de classificação do Guia, que normalmente querem saber mais detalhes dos estabelecimentos (querem falar com o repórter que esteve lá) e escrevem ou telefonam para o atendimento ao leitor reclamando ou elogiando um hotel ou restaurante. Em poucos casos, eles costumam co-responsabilizar o Guia pelo insucesso numa estada ou refeição. Quando isso acontece, o Guia envia cópia da carta do leitor reclamante ao estabelecimento e pede um esclarecimento; após o retorno, envia a resposta do hotel ou restaurante ao leitor, lamentando o ocorrido e deixando claro que o Guia não tem o poder de punir um estabelecimento. No entanto, como o leitor do Guia é solidário e participativo (chegam vinte e cinco mil cartas anualmente só do Guia Brasil) de uma forma ou de outra, ele pode influir: em alguns casos, as reclamações se repetem e vão sendo registradas pelo editor e, às vezes, forma-se uma espécie de parceria involuntária, uma cumplicidade entre o repórter e o leitor, quando o primeiro (sem saber das reclamações) propõe alteração na categoria ou classificação do estabelecimento.

Com a depuração das categorias de hotéis iniciada no Guia Brasil 1996 (passando de 7 para 5) e da nova classificação de restaurantes (pela qualidade da comida e não mais pelo conforto das instalações) houve um maior interesse dos estabelecimentos em relação aos critérios do Guia. O Guia explica que seus critérios de classificação visam atender única e exclusivamente ao leitor, não sendo função do Guia, auxiliar ou agir como consultor dessa área. De acordo com informações dos editores do Guia, sempre há os descontentes, que acham que seu estabelecimento é melhor do que o outro, mas como o Guia faz este tipo de trabalho há trinta e dois anos, sempre com isenção e independência editorial, não há muita discussão sobre os critérios utilizados.

A partir da descrição acima, pode-se dizer que a metodologia do Guia Quatro Rodas em relação à classificação dos meios de hospedagem é muito objetiva, deixando bem claro que o seu interesse é informar os seus usuários sobre os hotéis e não servir como consultor da área de hospedagem. Assim, sua forma de trabalho não deixa dúvidas em relação à postura adotada, pois além de não cobrar dos meios de hospedagem à classificação do mesmo no guia, todas as despesas com transporte, hospedagem, alimentação dos repórteres são pagas pela própria editora. Com esse tipo de atitude, o guia evita tentativas de subornos por parte dos meios de hospedagem para que os classifique em uma categoria melhor do que a que realmente lhes cabe.

Como ainda existe uma confusão nos sistemas oficiais de classificação de meios de hospedagem, por intermédio do antigo e do novo modelo de classificação, o Guia Quatro Rodas tem assumido o papel de referência para a classificação de hotéis, por ser atualizado anualmente e com reavaliações constantes. Mas mesmo assim, ainda fica difícil para o turista entender, pois a classificação que o Guia Quatro Roda usa é representada pelo 
número de casinhas, seguindo outros critérios e, o cliente só assimilou e está acostumado com as características das estrelas, que é uma referência internacional e que dificilmente isso será mudado. 


\subsubsection{ROTEIROS DE CHARME}

A Roteiros de Charme é uma associação de hotéis independentes que procura relacionar estabelecimentos que ofereçam qualidade diferenciada no atendimento aos hóspedes e que se destaquem pelo charme, requinte e bom gosto de suas instalações.

Atualmente, a Associação Roteiros de Charme reúne trinta e seis hotéis associados, que se beneficiam de infra-estrutura comum de reservas, divulgação comercial e jornalística, participação em eventos turísticos, etc.

Nos Roteiros de Charme, encontram-se desde refúgios ecológicos e pequenas pousadas, cujo atendimento é caseiro e despretensioso, a hotéis muito confortáveis, com requinte, estilo e serviço esmerado. De acordo com a Associação Roteiros de Charme ${ }^{2}$ são utilizadas pedras semi e preciosas brasileiras para orientar a escolha do usuário Elas identificam os diversos tipos de hospedagem oferecidos por toda a cadeia Roteiros de Charme, da seguinte forma:

Ametista - Um refúgio ecológico onde a decoração e os serviços simples guardam identidade com o local;

Água-Marinha - Um Hotel ou Pousada em local agradável, simples e confortável, de serviços que guardam identidade caseira com qualidade, cuja decoração reflita a cultura local;

Topázio Imperial - Um Hotel ou Pousada muito confortável, bem equipado, aconchegante, com serviços esmerados, estilo e decoração requintada;

Esmeralda - Um aconchegante Hotel ou Pousada com conforto, instalações e serviços que atendam os padrões de exigência da tradicional hotelaria internacional.

De acordo com informações fornecidas pela Associação Roteiros de Charme, para ingressar na associação há uma filosofia comum a ser partilhada e exigências a serem atendidas, que são:

O primeiro passo é a identificação do charme, que apesar da diversificada listagem da associação, onde constam refúgios ecológicos, fazendas, hotéis confortáveis e alguns bastante sofisticados, sendo qual for a característica de estilo, o que importa é o charme. Esse conceito subjetivo que significa genericamente uma união entre bom gosto, atenção com detalhes, paixão de servir, conforto compatível com expectativas dos hóspedes,

\footnotetext{
${ }^{3}$ Fonte: http://www.roteirosdecharme.com.br/. Acesso em: 25 Out 2003.
} 
localização privilegiada, construção adequada ao meio ambiente e à região, enfim, o conjunto de fatores que emprestam personalidade única ao local e ao próprio hotel.

O perfil do meio de hospedagem é o segundo passo; deve estar em funcionamento há pelo menos dois anos sob a mesma administração, para que tenha consolidado seu perfil e padrão de serviços; deverá ter de seis a sessenta apartamentos e/ou suítes, sendo que exceções somente serão admitidas com aprovação unânime da Diretoria; a localização deve ser preferencialmente em pontos de interesse turístico, histórico ou ecológico.

Depois de conceitos aceitos, etapas cumpridas, o terceiro passo é o processo de inscrição que se inicia com a remessa para a Sede da Associação de correspondência que inclua carta de intenção, descrição das instalações e serviços, fotografias, folhetos e, se for o caso, matérias publicadas na imprensa.

O quarto passo é a avaliação, quando a diretoria da associação estiver de posse das informações, iniciará as avaliações que incluem visita anônima de um diretor. Se categórica, a posição negativa resultará em correspondência afim. Se positiva a apreciação, a diretoria da associação, em contato direto com os proprietários, informará sobre os princípios associativos, estatutos e demais normas da associação. A diretoria decidirá pela aprovação e classificação após receber correspondência comunicando o "de acordo" do candidato quanto às normas e estatutos da associação.

As candidaturas são analisadas em abril de cada ano e julgadas uma vez por ano, em reuniões sucessivas da diretoria nos meses de junho, julho e agosto. Após o ingresso, os hotéis associados permanecem independentes, respeitados os princípios associativos.

Serão beneficiados, na avaliação, os hotéis cujos proprietários estejam envolvidos na administração e controle de qualidade.

A associação conta com um programa de fidelidade, que oferece aos hóspedes a possibilidade de utilizar acomodações superiores às reservadas, diárias de cortesia em fins de semana e a oportunidade de colaborar com a entidade, verificando a qualidade dos hotéis associados, por intermédio de visitas anônimas.

O hóspede deverá solicitar um "Guia-passaporte”3 em uma de suas estadias em qualquer dos hotéis associados. A partir desta hospedagem, ele se tornará um "Roteirista”״ se, no período de um ano, hospedar-se em quatro diferentes hotéis associados. A partir da data de sua hospedagem no quarto hotel , o hóspede deverá solicitar à associação o "Cartão de Roteirista". A apresentação deste cartão, durante os doze meses seguintes, contados a partir da quarta hospedagem, dará direito acomodações (up grade) superiores às que tiverem

\footnotetext{
${ }^{4}$ Programa de fidelidade utilizado pela Associação Roteiros de Charme.

${ }^{5}$ Hóspede que é participante do programa de fidelidade.
} 
sido reservadas e desde que haja, no momento de seu registro no hotel (check-in), disponibilidade de apartamento do tipo imediatamente superior àqueles que tiver reservado.

Hospedando-se em oito diferentes hotéis associados no período de dois anos consecutivos, contados a partir da oitava hospedagem, o hóspede passará a "Roteirista Sênior”. Com isso, o hóspede terá direito a duas diárias em hotel ou pousada de sua preferência durante os doze meses seguintes. A reserva dessas diárias deverá ser feita por intermédio da associação e sempre se dará segundo a disponibilidade, e de acordo com a quota de premiação estabelecida a exclusivo critério desta associação, em função do período de alta ou baixa estação e do número de apartamentos de cada associado. Os períodos de exceção para as diárias-cortesias são: em qualquer época, nos associados com menos de nove apartamentos e em estabelecimentos não incluídos no Guia Passaporte do ano da premiação; nos períodos de férias escolares, nos pacotes promocionais e nos fins-de-semana prolongados em todos os demais hotéis.

Completando mais duas estadas em diferentes hotéis totalizando, portanto, a hospedagem em dez diferentes hotéis associados no período de dois anos consecutivos, o hóspede passa a ser considerado um “Roteirista Expert”. Assim, o hóspede é convidado para dois dias de hospedagem incógnita em um dos hotéis cuja escolha ficará a critério e conveniência da associação, devendo fazer observações, críticas e sugestões, sendo que ele já é um hóspede familiarizado com a proposta da associação, ajudará a manter o padrão desejado. Assim, será a visão do hóspede complementando e aperfeiçoando a visão profissional de cada hoteleiro.

Os métodos utilizados pela Roteiros de Charme para classificar os meios de hospedagem são rígidos, mas assim, deixam bem claro que os seus objetivos estão sendo cumpridos. 


\section{CONCLUSÃO}

Nos últimos anos diversas cadeias internacionais estão chegando ao Brasil, trazendo novas tecnologias e marcas reconhecidas internacionalmente.

Até então o Brasil sofria uma oferta de empreendimentos hoteleiros por diversas razões, mas a principal delas era a falta de analise do mercado.

Com as cadeias internacionais geralmente padronizadas em termos de serviço e infraestrutura, captando clientes estrangeiros já habitues de sua marca, os hoteleiros tradicionais e familiares terão que rapidamente se adaptar as novas mudanças e exigências dos clientes.

Um dos meios de garantir credibilidade e confiabilidade por meio dos turistas e e demais empreendimentos é a nova Classificação dos Meios de Hospedagem regido pela Embratur, que garante ao hoteleiro que seu hotel será referência interna e externamente.

Conclui-se nessa pesquisa que a classificação ainda não consegue ser um referencial de orientação para clientes e empreendedores também, por que, existem diversos sistemas de classificação, e antes da nova matriz a classificação já havia causado grande insatisfação e falta de credibilidade aos consumidores.

O mercado externo não reconhece nossa matriz e acaba por optar por redes internacionais conhecidas lá fora. Para os empreendedores é mais garantido em termos de retorno formar parcerias com cadeias internacionais.

Sobre a classificação não atender aos anseios e expectativas do cliente, a hipótese foi confirmada, pois apesar da nova matriz estar atendendo a questões referentes a qualidade de serviços , os anseios de cada cliente são relativos e diferentes, logo, é muito difícil atender a todas as diversas solicitações.

Referente à classificação não ser flexível com relação as peculiaridades de diferentes regiões, a hipótese não se confirmou. Hoje a classificação continua sendo extremamente rígida, mas enquanto a antiga não permitia nenhuma regalia a nova abre exceções desde que o empreendimento justifique e convença de as diferenças tem real significância para o empreendimento.

Com relação a validade ou não da classificação da Embratur, conclui-se de que é muito cedo para verificarmos um retorno de investimento para os hotéis já classificados. Até o momento não conseguimos provar essa hipótese. O que pode-se observar é que o primeiro retorno sentido para os hotéis já classificados foi a mudança, para melhor, do cliente interno, ou seja, os funcionários, que por terem participado de um processo tão longo de mudanças e readaptação a novos conceitos e quebra de paradigmas tem dado maior valor ao atendimento ao cliente. 
Já as cadeias como a Atlantica tem garantido sua posição no mercado pois tem uma renomada marca conhecida externamente e com a globalização cada vez se consolidam mais.

O pesquisador deixa como sugestão que posteriormente se faça uma nova pesquisa para verificar resultados concretos obtidos nos hotéis já classificados. Mas, conclui que se os novos padrões da classificação funcionarem, os empreendimentos que não aderirem ao processo correm o sério risco de deixarem de existir, devido aos altos padrões de exigência dos clientes e aos altos padrões de oferta dos empreendimentos. 


\section{BIBLIOGRAFIA}

CASTELLI, Geraldo. Administração Hoteleira. 8. ed. Caxias do Sul: Educs, 2001. Excelência em Hotelaria. 3. ed. Rio de Janeiro: Qualitymark, 1998.

COOPER, Chris; et al. Turismo: princípios e prática. Tradução: Roberto Cataldo Costa. 2. ed. Porto Alegre: Bookman, 2001.

EMBRATUR. Estudo econômico-financeiro dos meios de hospedagem e parques temáticos no Brasil. Brasília: Ministério da Indústria do Comércio e do Turismo, 1998.

LUZ, Mauro Catharino Vieira da (org.). Análise Setorial: a indústria hoteleira, em panorama setorial Gazeta Mercantil. São Paulo: Gazeta Mercantil, 1999.

VIEIRA DA LUZ, Mauro Catharino (org.). Análise Setorial: a indústria hoteleira, em panorama setorial Gazeta Mercantil. São Paulo: Gazeta Mercantil, 1999.

Manual e Matriz de Classificação, nov, 2003. Seção Classificação. Disponível na internet em: http://www.abih.gov.br/classificação/manual/matriz/hoteis classificados>,acesso em 15 out 2003.

Deliberação Normativa da Embratur, abr 2002. Disponível na internet em: http://www.embratur.gov.br/legislaçao>,acesso em 15 out 2003.

Evolução do Turismo no Brasil , 2002. Disponível na internet em: http://www.embratur.gov.br/dados e fatos>,acesso em 15 out 2003. 
ANEXOS 


\section{ANTIGO SISTEMA DE CLASSIFICAÇÃO - EMBRATUR}

De acordo com o Regulamento dos Meios de Hospedagem aprovado por intermédio da Deliberação Normativa $n^{0}$ 387, de 28 de Janeiro de $1998,{ }^{5}$ os meios de hospedagem estavam assim caracterizados:

Os tipos básicos de meios de hospedagem de turismo, com as características distintivas são os seguintes:

I - Hotel - meio de hospedagem do tipo convencional e mais comum, normalmente localizado em perímetro urbano e destinado a atender turistas, tanto em viagens de lazer, quanto em viagens de negócios;

II - Hotel Histórico - meio de hospedagem instalado, total ou parcialmente, em edificação de valor histórico ou de significado regional ou local reconhecido pelo Poder Público e que, em razão disto, está normalmente sujeito a restrições de natureza arquitetônica e construtiva;

III - Hotel de Lazer - meio de hospedagem normalmente localizado fora dos centros urbanos, com áreas não edificadas, amplas e com aspectos arquitetônicos e construtivos, instalações, equipamentos e serviços especificamente destinados à recreação e ao entretenimento, que o tornam prioritariamente destinado ao turista em viagem de lazer;

IV - Pousada - meio de hospedagem de aspectos arquitetônicos e construtivos, instalações, equipamentos e serviços mais simplificados, normalmente limitados apenas ao necessário à hospedagem do turista para aproveitamento do atrativo turístico, junto ao qual o estabelecimento se situa.

Atendidas as disposições deste Regulamento e da matriz de classificação aplicável, os meios de hospedagem de turismo eram classificados em categorias representadas de uma a cinco estrelas respectivamente: Simples; Standard; Standard Superior; Luxo; e Luxo Superior.

O processo de classificação oficial dos meios de hospedagem de turismo pela Embratur tinha como princípios básicos:

I - A classificação dependia da comprovação do atendimento aos critérios de classificação deste regulamento;

II - A comprovação do atendimento aos critérios de classificação era verificada em avaliação procedida por Organismos Certificadores Credenciados (OCC) pelo Instituto Nacional de Metrologia, Normalização e Qualidade Industrial - INMETRO, observadas as

\footnotetext{
${ }^{6}$ CASTELLI,Geraldo. Administração Hoteleira. p. 656-661.
} 
disposições deste Regulamento e da Matriz de Classificação aplicável ao tipo e à categoria pretendidos pelo meio de hospedagem;

III - A avaliação consistia na comparação e na verificação da conformidade entre os padrões existentes no meio de hospedagem e aqueles previstos, para a categoria de classificação por ele pretendida, nos diversos itens da Matriz de Classificação;

IV - Os Organismos Certificadores Credenciados executavam a avaliação por intermédio de avaliadores qualificados, em função da sua formação e experiência profissional e capacitação em cursos de formação específica, ministrados por Organismos de Treinamento Credenciados;

V - A sistemática para credenciamento de Organismos Certificadores Credenciados OCC - e Organismos de Treinamento - OT, bem como para certificação de avaliadores e supervisão da certificação de meios de hospedagem, obedeciam às normas estabelecidas pelo INMETRO, como agente operativo, normativo e fiscalizador do Sistema Brasileiro de Certificação - SBC.

Os meios de hospedagem que desejavam obter a classificação na Embratur pelo antigo sistema de classificação - reforçando que com o novo sistema, os meios de hospedagem já estão se adequando neste novo modelo - deveriam seguir as seguintes etapas:

I - Realizavam uma pré-avaliação do seu estabelecimento, em função dos critérios e padrões da Matriz de Classificação, utilizando-se, preferencialmente, de pessoal próprio, ou de firma consultora, capacitado a proceder à avaliação de meios de hospedagem;

II - Implementavam, por meios próprios ou com assessoria especializada, as melhorias necessárias à obtenção da conformidade entre os padrões existentes no meio de hospedagem e aqueles previstos para a categoria pretendida;

III - Solicitavam, assim que julgassem estar seu estabelecimento conforme os padrões exigidos, a avaliação do OCC de sua preferência, para fins de certificação do atendimento às normas classificatórias;

IV - Celebravam contrato com o OCC para a realização da avaliação inicial e das vistorias anuais de verificação da manutenção da certificação;

V - Solicitavam a classificação, por intermédio do Órgão Estadual de Turismo competente em sua Unidade de Federação, ou diretamente à Embratur, encaminhando os documentos solicitados;

VI - Recebiam o documento que lhe fosse conferido pela Embratur, atestando a classificação, e afixavam a placa de classificação que lhe fora atribuída, na fachada principal do estabelecimento, junto à porta de entrada, em local de máxima visibilidade para o hóspede; 
VII - Apresentavam ao Órgão Estadual de Turismo competente, ou diretamente a Embratur, cópia dos certificados, fornecidos pelo OCC respectivo, relativos aos dois exercícios seguintes ao da avaliação completa, sob pena de suspensão ou cancelamento da certificação que lhe fora atribuída, com a retirada da respectiva placa e devolução do certificado de classificação.

A classificação do meio de hospedagem pela Embratur era procedida verificando-se a compatibilidade e a conformidade entre os padrões existentes no estabelecimento e aqueles previstos nas matrizes de classificação aplicáveis.

A Matriz de Classificação era constituída por padrões comuns e específicos aos diversos tipos e categorias de meios de hospedagem de turismo, apresentados em itens, devidamente numerados e seqüenciados.

Os itens e padrões definidos na matriz de classificação tinham por objetivo atender às expectativas dos hóspedes, em relação aos meios de hospedagem de turismo, destinando-se a avaliar a observância dos seguintes aspectos:

Itens Gerais - de aplicação ao meio de hospedagem como um todo: posturas legais; segurança; saúde/higiene; conservação/manutenção e; atendimento ao hóspede;

Itens Específicos - destinado a avaliar os diferentes setores do meio de hospedagem: portaria/recepção; acessos e circulações; setor habitacional; áreas sociais; comunicações; alimentos e bebidas; lazer; convenções/escritório virtual e; serviços adicionais.

Os padrões referidos verificavam, dentro de cada item, os serviços prestados pelo estabelecimento, os sistemas de gestão adotados, as instalações e equipamentos disponíveis e as áreas e aspectos construtivos existentes no meio de hospedagem de turismo que, analisados em conjunto, possibilitavam aferir os níveis de conforto e atendimento oferecidos aos consumidores.

As especificações de cada item/padrão da Matriz de Classificação, bem como de sua forma de avaliação, eram expressas em manuais elaborados pela Embratur.

A partir da descrição acima, houve uma melhora significativa em relação ao antigo sistema de classificação dos meios de hospedagem que foi cancelado por intermédio da Deliberação Normativa n ${ }^{\circ} 360$ de 16 abril de 1996, onde: procederam correções no texto do manual de avaliação do tipo "Hotel"; procederam correções em todo o Regulamento dos Meios de Hospedagem, inclusive alterando integralmente sobre o processo de classificação, controle e fiscalização; incorporaram ao regulamento a matriz de classificação e o manual de avaliação para o tipo “Hotel de Lazer”; e incorporaram os impressos denominados "Ficha Nacional de Registro de Hóspedes - FNRH" e "Boletim de Ocupação Hoteleira - BOH".

Um dos fatores que geraram a falta de interesse da maior parte dos meios de hospedagem, para obter o registro oficial da Embratur, foi o preço, pouco convidativo, 
girando em torno de U\$ 6 mil. Por isso, somente alguns dos hotéis de grande porte acabaram pagando, muitas vezes para provar aos clientes que possuíam o padrão oficial mais alto. Os hotéis de médio e pequeno porte, mesmo que tivessem interesse em participar, não teriam condições financeiras para realizar a classificação.

A antiga Matriz de Classificação Hoteleira, para algumas categorias, não permitia exceções em hotéis com localização geográfica diferentes e não atendia a nenhum tipo de particularidades e peculiaridades de cada hotel, como exemplo: a obrigatoriedade de piscinas em hotéis em São Paulo, o que normalmente, os hóspedes não utilizam por serem na maioria, de viagens de negócios; a exigência de carpete nos apartamentos em hotéis de litoral, o que torna desconfortável para o hóspede e cresce muito o serviço de manutenção dos mesmos; a exigência de aparelhos de ar-condicionado em hotéis nas cidades de Gramado e Canela, onde seria muito mais apropriado o uso de lareira ou calefação, entre outros. 


\section{NOVA CLASSIFICAÇÃO DA EMBRATUR}

\subsection{DELIBERAÇÃO NORMATIVA Nº, DE 2002.}

A Diretoria da EMBRATUR - Instituto Brasileiro de Turismo, no uso de suas atribuições legais e estatutárias, considerando a competência atribuída a este Instituto, nos termos do artigo $4^{\circ}$, da Lei $n^{\circ}$ 6.505, de 13 de dezembro de 1977; do inciso X, do artigo $3^{\circ}$, da Lei 8.181, de 28 de março de 1991; e do Decreto n 84.010, de 15 de julho de 1980,

Considerando o Termo de Compromisso firmado em 11 de abril de 2001, entre o Ministério do Esporte e Turismo, por meio da EMBRATUR - Instituto Brasileiro de Turismo e a Associação Brasileira da Indústria de Hotéis - ABIH Nacional, publicado no DOU, de 03 de julho de 2001, visando definir parâmetros para instituir um novo Sistema de Classificação dos Meios de Hospedagem; RESOLVE:

Art. $1^{\circ}$ - Aprovar os anexos Regulamento Geral dos Meios de Hospedagem e Regulamento do Sistema Oficial de Classificação dos Meios de Hospedagem, para os fins estabelecidos no artigo $4^{\circ}$, da Lei 6.505, de 13 de dezembro de 1977; no inciso X, do artigo $3^{\circ}$, da Lei 8.181, de 28 de março de 1991; e no Decreto 84.910, de 15 de julho de 1980.

Art. $2^{\circ}$ - Os documentos mencionados no artigo anterior são o resultado da conclusão dos trabalhos realizados pelo Conselho Técnico Nacional Provisório, instituído pela Deliberação Normativa ${ }^{\circ}$ 428, de 29 de novembro de 2002, publicada no Diário Oficial da União, de 11 de janeiro de 2002.

Art. $3^{\circ}$ - Os Regulamentos ora instituídos modificam o Regulamento dos Meios de Hospedagem, o Manual de Avaliação e a Matriz de Classificação criados pela Deliberação Normativa ${ }^{\circ}$ 387, de 28 de janeiro de 1998, publicada no Diário Oficial da União $n^{\circ}$ 27, de 09/02/98, nos seguintes aspectos básicos:

I - modifica o Regulamento Geral dos Meios de Hospedagem;

II - altera integralmente o processo de classificação dos meios de hospedagem;

III - procede alterações no Manual de Avaliação e na Matriz de Classificação dos Meios de Hospedagem

IV - incorpora ao Regulamento Geral dos Meios de Hospedagem, como anexos I e II os impressos denominados, respectivamente, "Ficha Nacional de Registro de Hóspedes FNRH" e "Boletim de Ocupação Hoteleira - BOH";

V - Incorpora, igualmente, no Regulamento do Sistema Oficial de Classificação dos Meios 
de Hospedagem os anexos III e IV , denominados Manual de Avaliação e Matriz de Classificação;

VI - consolida disposições dispersas na legislação, concernente à atividade hoteleira.

Art. $4^{\circ}$ - Esta Deliberação Normativa entra em vigor na data de sua publicação no Diário Oficial da União, revogada a Deliberação Normativa n 387, de 28 de janeiro de 1998, publicada no DOU de 09/02/1998. 


\subsection{REGULAMENTO GERAL DOS MEIOS DE HOSPEDAGEM}

Art. $1^{\circ}$ - O presente Regulamento dispõe sobre os Meios de Hospedagem, estabelecendo:

I - o conceito de empresa hoteleira, meio de hospedagem e as expressões usualmente consagradas no exercício da atividade;

II - os requisitos exigidos para operação e funcionamento dos estabelecimentos;

III - as condições para contratação dos serviços de hospedagem.

Art. $2^{\circ}$ - Considera-se empresa hoteleira a pessoa jurídica, constituída na forma de sociedade anônima ou sociedade por quotas de responsabilidade limitada, que explore ou administre meio de hospedagem e que tenha em seus objetivos sociais o exercício de atividade hoteleira, observado o Art. $4^{\circ}$ do Decreto $n^{\circ} 84.910$, de 15 de julho de 1980.

Art. $3^{\circ}$ - Considera-se meio de hospedagem o estabelecimento que satisfaça, cumulativamente, às seguintes condições:

I - seja licenciado pelas autoridades competentes para prestar serviços de hospedagem;

II - seja administrado ou explorado comercialmente por empresa hoteleira e que adote, no relacionamento com os hóspedes, contrato de hospedagem, com as características definidas neste Regulamento e nas demais legislações aplicáveis;

Parágrafo único - Observadas as disposições do presente Regulamento, os meios de hospedagem oferecerão aos hóspedes, no mínimo:

I - alojamento, para uso temporário do hóspede, em Unidades Habitacionais (UH) específicas a essa finalidade;

II - serviços mínimos necessários ao hóspede, consistentes em:

a) Portaria/recepção para atendimento e controle permanentes de entrada e saída;

b) Guarda de bagagens e objetos de uso pessoal dos hóspedes, em local apropriado;

c) Conservação, manutenção, arrumação e limpeza das áreas, instalações e 
equipamentos.

III - padrões comuns estabelecidos no Art. $7^{\circ}$ deste Regulamento.

Art. $4^{\circ}$ - Unidade Habitacional-UH é o espaço, atingível a partir das áreas principais de circulação comuns do estabelecimento, destinado à utilização pelo hóspede, para seu bem-estar, higiene e repouso.

Art. $5^{\circ}$ - Quanto ao tipo, as UH dos meios de hospedagem são as seguintes:

I - quarto - UH constituída, no mínimo, de quarto de dormir de uso exclusivo do hóspede, com local apropriado para guarda de roupas e objetos pessoais.

II - apartamento - UH constituída, no mínimo, de quarto de dormir de uso exclusivo do hóspede, com local apropriado para guarda de roupas e objetos pessoais, servida por banheiro privativo;

III - suíte - UH especial constituída de apartamento, conforme definido no inciso II, deste artigo, acrescido de sala de estar.

$\S 1^{\circ}$ - Poder-se-á admitir, especialmente para determinados tipos de meios de hospedagem a serem definidos pela EMBRATUR, Unidades Habitacionais distintas daquelas referidas neste artigo.

$\S 2^{\circ}$ - As UH poderão ser conjugadas e adaptadas para funcionamento como sala de estar e/ou quarto de dormir, sendo, entretanto, sempre consideradas, para efeito de avaliação, como duas ou mais UH distintas.

Art. $6^{\circ}$ - Entende-se por diária o preço de hospedagem correspondente à utilização da UH e dos serviços incluídos, observados os horários fixados para entrada (check-in) e saída (check-out).

$\S 1^{\circ}$ - O estabelecimento fixará o horário de vencimento da diária à sua conveniência ou de acordo com os costumes locais ou ainda conforme acordo direto com os clientes

$\S 2^{\circ}$ - Poderão ocorrer formas diferenciadas de cobrança de diária, conforme conveniência e acordo entre o meio de hospedagem e os hóspedes.

$\S 3^{\circ}$ - Quando não especificado o número de ocupantes da UH, a diária básica referir- 
se-á, sempre, à ocupação da UH por duas pessoas.

Art. $7^{0}$ - Os padrões comuns a todos os meios de hospedagem são os seguintes:

I - Quanto a posturas legais:

a) licenciamento pelas autoridades competentes para prestar serviços de hospedagem, inclusive dos órgãos de proteção ambiental;

b) administração ou exploração comercial, por empresa hoteleira, conforme o Art. $2^{\circ}$ deste Regulamento;

c) oferta de alojamento temporário para hóspedes, mediante adoção de contrato, tácito ou expresso, de hospedagem e cobrança de diária, pela ocupação da UH;

d) exigências da legislação trabalhista, especialmente no que se refere a vestiários, sanitários e local de refeições de funcionários e Comissões de Prevenção de Acidentes de Trabalho - CIPA.

II - Quanto a aspectos construtivos:

a) edificações construídas ou expressamente adaptadas para a atividade;

b) áreas destinadas aos serviços de alojamento, portaria/recepção, circulação, serviços de alimentação, lazer e uso comum, e outros serviços de conveniência do hóspede ou usuário, separadas entre si e no caso de edificações que atendam a outros fins, independente das demais;

c) proteção sonora, conforme as normas da Associação Brasileira de Normas Técnicas - ABNT - e legislação aplicáveis;

d) salas e quartos de dormir das UH dispondo de aberturas para o exterior, para fins de iluminação e ventilação;

e) todos os banheiros dispondo de ventilação natural, com abertura direta para o exterior, ou através de duto;

f) serviços básicos de abastecimento de água que não prejudiquem a comunidade local, bem como de energia elétrica, rede sanitária, tratamento de efluentes e coleta de resíduos sólidos, com destinação adequada;

g) facilidades construtivas, de instalações e de uso, para pessoas com necessidades especiais, de acordo com a NBR 9050 - 1994, em prédio com projeto de arquitetura aprovado pela Prefeitura Municipal, como meio de hospedagem, após 12 de agosto de 1987. Em caso de projetos anteriores, o meio de hospedagem deverá dispor de sistema 
especial de atendimento.

III - Quanto a equipamentos e instalações:

a) instalações elétricas e hidráulicas de acordo com as normas da Associação Brasileira de Normas Técnicas - ABNT - e legislação aplicável;

b) instalações de emergência, para a iluminação de áreas comuns e para o funcionamento de equipamentos indispensáveis à segurança dos hóspedes; c) elevador para passageiros e cargas, ou serviço, em prédio com quatro ou mais pavimentos, inclusive o térreo, ou conforme posturas municipais;

d) instalações e equipamentos de segurança contra incêndio e pessoal treinado a operálo, de acordo com as normas estabelecidas e pelo Corpo de Bombeiros local; e) quarto de dormir da UH mobiliado, no mínimo, com cama, equipamentos para a guarda de roupas e objetos pessoais, mesa-de-cabeceira e cadeira.

IV - Quanto a serviços e gestão:

a) portaria/recepção apta a permitir a entrada, saída, registro e liquidação de conta dos hóspedes, durante as 24 horas do dia;

b) registro obrigatório do hóspede no momento de sua chegada ao estabelecimento, por meio de preenchimento da Ficha Nacional de Registro de Hóspedes - FNRH, aprovada pela EMBRATUR;

c) limpeza e arrumação diária da UH, fornecimento e troca de roupa de cama e banho, bem como de artigos comuns de higiene pessoal, por conta do estabelecimento;

d) serviços telefônicos prestados aos hóspedes de acordo com os regulamentos internos dos estabelecimentos e as normas e procedimentos adotados pelas concessionárias dos serviços, ou pelo poder concedente;

e) imunização permanente contra insetos e roedores;

f) pessoal de serviço em quantidade e com a qualificação necessárias ao perfeito funcionamento do meio de hospedagem;

g) pessoal mantido permanentemente uniformizado e/ou convenientemente trajado, de acordo com as funções que exerçam;

h) meios para pesquisar opiniões e reclamações dos hóspedes e solucioná-las;

i) observância das demais normas e condições necessárias à segurança, saúde/higiene e conservação/manutenção do meio de hospedagem, para atendimento ao consumidor. 
$\S 1^{\circ}$ - Nas localidades não servidas ou precariamente servidas por redes de serviços públicos, a satisfação dos itens obrigatórios, cujo atendimento dependa da existência dessas redes, será apreciada, caso a caso, pela EMBRATUR.

$\S 2^{\circ}$ - Serão exigidas condições específicas de proteção, observadas as normas e padrões estabelecidos pelos órgãos governamentais competentes, para os meios de hospedagem localizados no interior ou nas proximidades de:

a) unidades de conservação, ou protegidas pela legislação ambiental vigente; b) aeroportos, estações viárias, vias industriais, ou estabelecimentos que ofereçam problemas especiais de poluição ambiental e sonora.

$\S 3^{\circ}$ - As portas entre UH conjugáveis deverão dispor de sistema que somente possibilite sua abertura, quando por iniciativa mútua dos ocupantes de ambas as UH.

$\S 4^{\circ}$ - As condições dos locais de trabalho e de uso dos empregados, no estabelecimento, serão mantidas, no que se refere à segurança, higiene e medicina do trabalho, em estrita observância ao disposto na Consolidação das Leis de Trabalho, ou nos atos que a modifiquem.

Art. $8^{\circ}$ - Os contratos para reserva de acomodações e hospedagem deverão ser sempre consubstanciados por documentos escritos, constituídos de: I - no caso de reserva de acomodações: troca de correspondências (inclusive via fax e Internet) entre os responsáveis pelo meio de hospedagem, ou seus prepostos, e o hóspede, ou agente de turismo contratante;

II - no caso do contrato de hospedagem propriamente dito pela entrega pelo estabelecimento, durante o registro do hóspede (check-in), de ficha Nacional de Registro de Hóspede - FNRH, em modelo aprovado pela EMBRATUR, para preenchimento, assinatura e devolução pelo hóspede;

$\S 1^{\circ}$ - Respeitadas as reservas confirmadas, o estabelecimento não poderá se negar a receber hóspedes, salvo por motivo justificável ou previsto na legislação em vigor.

$\S 2^{\circ}$ - Será vedada a utilização, em qualquer procedimento ou documento que consubstancie o contrato referido neste artigo, de condição ou cláusula abusiva a que se refere o artigo 51, da Lei nº 8.078, de 11/09/90 (Código de Defesa do Consumidor). 
$\S 3^{\circ}$ - Para os fins deste artigo, todos os compromissos do meio de hospedagem e os em relação a seus hóspedes, bem como as obrigações destes deverão ser divulgados adequadamente.

$\S 4^{0}$ - As informações referidas no parágrafo anterior deverão estar à disposição, do hóspede, sempre que solicitado.

$\S 5^{\circ}$ - Os responsáveis pelos meios de hospedagem deverão garantir prioridade de ocupação a pessoas portadoras de deficiência, nas UH adaptadas para seu uso.

Art. $9^{\circ}$ - Os meios de hospedagem deverão fornecer mensalmente, ao Órgão Estadual de Turismo competente, da Unidade da Federação em que se localizarem, as seguintes informações:

I - perfil dos hóspedes recebidos, distingüindo os estrangeiros dos nacionais;

II - registro quantitativo de hóspedes, com taxas de ocupação e permanência médias e número de hóspedes por UH.

Art. 10- Para os fins do artigo anterior, os meios de hospedagem utilizarão, obrigatoriamente, as informações previstas nos impressos Ficha Nacional de Registro de Hóspedes - FNRH - e Boletim de Ocupação Hoteleira - BOH, constantes dos anexos I e II, deste Regulamento.

$\S 1^{\circ}$ - Às informações da Ficha Nacional de Registro de Hóspedes - FNRH - poderá ser acrescida alguma outra, de interesse do hoteleiro, desde que não prejudique o entendimento e o preenchimento do modelo de ficha oficial.

$\S 2^{\circ}$ - A FNRH poderá ser preenchida, individualmente, pelo hóspede, ou pelo próprio estabelecimento, devendo suas informações serem encaminhadas, juntamente com o $\mathrm{BOH}$, até o dia 10 do mês seguinte ao de referência, por meios magnéticos, de acordo com o sistema oferecido pela EMBRATUR, ou através dos impressos utilizados.

$\S 3^{\circ}$ - As informações relativas a cada hóspede, constantes da FNRH, serão mantidas pelo período determinado pela autoridade policial competente em cada Estado, ou, na ausência desta determinação, por um período mínimo de 3 meses.

Art. 11 - A FNRH e o BOH, após devidamente processados, informarão, 
respectivamente, o perfil dos hóspedes e as taxas de ocupação médias, que serão postos à disposição do mercado, sem identificação individualizada dos estabelecimentos, pelos Órgãos Estaduais de Turismo.

Art. 12 - O meio de hospedagem deverá incluir nos impressos distribuídos, ou nos meios de divulgação utilizados, ainda que de forma sintética e resumida, todos os compromissos recíprocos entre o estabelecimento e o hóspede, especialmente em relação a:

I - serviços incluídos no preço da diária;

II - importâncias ou percentagens que possam ser debitadas à conta do hóspede, inclusive, quando aplicável, o adicional de serviço para distribuição aos empregados;

III - locais e documentos onde estão relacionados os preços dos serviços não incluídos na diária, tais como estacionamento, lavanderia, telefonia, serviços de quarto e outros;

IV - possibilidade da formulação de reclamações para a EMBRATUR, para o Órgão Estadual de Turismo e para o órgão local de Defesa do Consumidor, cujos telefones devem ser divulgados.

Parágrafo único - Os Regulamentos Internos dos estabelecimentos deverão observar, fielmente, as disposições do Código de Defesa do Consumidor (Lei nº 8078/90).

Art. 13 - Os meios de hospedagem devem manter, na portaria/recepção, à disposição de seus hóspedes e usuários, livro ou outro documento próprio para registro das impressões, elogios e reclamações sobre o estabelecimento, cuja consulta periódica deverá orientar a sistematização de ações preventivas e corretivas de controle e de melhoria de qualidade do empreendimento.

Art. 14 - Todo e qualquer preço de serviço prestado e cobrado pelo meio de hospedagem deverá ser previamente divulgado e informado em impressos e outros meios de divulgação de fácil acesso ao hóspede.

Art. 15 - Para os fins do artigo anterior, os meios de hospedagem afixarão:

I - na portaria/recepção: 
a) nome do estabelecimento;

b) relação dos preços aplicáveis às espécies e tipos de UH;

c) horário do início e vencimento da diária;

d) os nomes, endereços e telefones da EMBRATUR, de seus órgãos delegados competentes, e de Defesa do Consumidor, aos quais os hóspedes poderão dirigir eventuais reclamações.

e) a existência e quantidade de UH adaptadas para pessoas portadoras de necessidades especiais

II - Nas Unidades Habitacionais-UH: além das informações referidas no inciso anterior, mais as seguintes:

a) a espécie e o número da UH;

b) os preços vigentes em moeda nacional;

c) os serviços incluídos na diária, especialmente, quando aplicáveis, os de alimentação;

d) a data de início de vigência das tarifas;

e) todos os preços vigentes dos serviços oferecidos pelo estabelecimento, tais como mini-refrigerador, lavanderia, ligações telefônicas, serviço de quarto e outros, afixados junto ao local em que esses serviços são oferecidos;

Parágrafo único - Havendo na mesma edificação, além das UH destinadas ao funcionamento normal do meio de hospedagem, outras para locação ou quaisquer finalidades diversas, o estabelecimento deverá expor em local de fácil visibilidade, na recepção, quantas e quais UH se destinam a cada finalidade.

Art. 16 - Os preços serão livremente fixados e praticados por todos os meios de hospedagem, observada a legislação pertinente.

Parágrafo único - Os preços serão sempre expressos em moeda nacional, admitindo-se, para fins promocionais, que os mesmos sejam divulgados no exterior em moeda estrangeira, observada a cotação correspondente prevista no câmbio oficial.

Art. 17 - É expressamente vedada a utilização de qualquer espécie de artifício ou documento, por meio de hospedagem, com o intuito de induzir o consumidor sobre classificação inexistente, ou diversa daquela efetivamente atribuída ao estabelecimento.

Parágrafo único - A adoção do procedimento referido neste artigo caracterizará a 
prática de propaganda enganosa mencionada na Lei $n^{\circ}$ 8.078/90 (Código de Defesa do Consumidor).

Art. 18 - Os meios de hospedagem que dispuserem de UH e áreas acessíveis a pessoas portadoras de deficiência deverão colocar, junto a entrada principal do estabelecimento, da placa com o Símbolo Internacional de Acesso a essa faixa de clientela.

Art. 19 - O serviço de portaria/recepção do meio de hospedagem - prioritário ao atendimento do consumidor - deverá dispor de pessoal qualificado e material promocional adequado a prestar as informações e atender as providências requisitadas pelos hóspedes.

Parágrafo único - O disposto neste artigo não justificará, em qualquer hipótese, a intermediação de serviços que constituam prática de atos atentatórios aos bons costumes e à legislação em vigor.

Art. 20 - O controle e fiscalização da EMBRATUR sobre os meios de hospedagem aplicar-se-ão, indistintamente, sobre os estabelecimentos classificados, ou não, pela EMBRATUR.

Art. 21 - As vistorias de controle e fiscalização serão realizadas diretamente pela EMBRATUR, ou por intermédio dos Órgãos Governamentais a quem a autarquia delegar estas atribuições, com o objetivo de:

I - Orientar os meios de hospedagem sobre as normas que regem sua atividade;

II - Verificar, no caso dos meios de hospedagem não classificados pela EMBRATUR, se existem padrões adequados ao exercício da atividade e se está sendo exercida de acordo com as normas governamentais de defesa do consumidor e com os compromissos prometidos ou explicitados para com o público e os clientes;

III - Apurar reclamações contra os meios de hospedagem ou indícios de infração por eles praticada.

Art. 22 - É dever dos meios de hospedagem cumprir e honrar, permanentemente, os contratos ou compromissos divulgados, explicitados ou acordados com o consumidor, especialmente as reservas e preços de hospedagem previamente ajustados. 
Art. 23 - A EMBRATUR deverá providenciar instrumental específico para controle e fiscalização dos meios de hospedagem não classificados, com o fim de verificar :

I - Se as posturas legais e os padrões de operação e funcionamento, previsto neste Regulamento, estão sendo fielmente observados pelos estabelecimentos;

II - Se existem padrões mínimos de qualidade adequados ao funcionamento do estabelecimento, como meio de hospedagem;

III - Se estão sendo atendidos os direitos do consumidor, previstos na legislação vigente.

Parágrafo único - Nos casos dos incisos II e III, deste artigo, a EMBRATUR e os Órgãos Governamentais por ela delegados comunicarão os fatos às autoridades competentes para aplicação das penalidades correspondentes, inclusive de interdição do exercício da atividade, quando for o caso.

Art. 24 - Os descumprimentos às disposições deste Regulamento, bem como das demais legislações aplicáveis, sujeitarão os meios de hospedagem às penalidades de advertência, pena pecuniária, suspensão ou cancelamento da classificação e/ou interdição do estabelecimento e fechamento da empresa, conforme o caso.

Art. 25 - As disposições constantes deste Regulamento serão aplicadas, a todos os meios de hospedagem.

Art. 26 - Os casos omissos e as interpretações de situações especiais de meios de hospedagem com condições atípicas serão decididas pela EMBRATUR.

Art. 27 - O presente Regulamento entra em vigor na data da publicação desta Deliberação Normativa no Diário Oficial da União. 


\subsection{Atlante Plaza Recife - 5 estrelas}

Segundo a assessora de comunicação da rede Pontes de Hotéis, Liane Cyreno a classificação relevou muito aspectos relacionados à prestação de serviços, pois exige o máximo de conforto segurança e qualidade de serviços, não só para os hospedes como para os funcionários que passam a trabalhar em melhores condições proporcionado um melhor serviço.

As normas para a estrutura física continuam sendo rígidas bem como a exigência de artigos e serviços nas unidades habitacionais.

Liane também afirmou que a classificação 5 Estrelas é muito respeitada e que o hotel tira grande proveito em termos de divulgação na mídia, pois o "5 Estrelas” é sinônimo de status, isso gera um retorno para empresa, pois a resposta ou o retorno de melhorias de receitas e ocupação não é imediatamente sentido pelo hotel.

Os hospedes sentem a grande mudança e a partir daí, de indicações dos próprios hospedes que perceberam a melhoria de serviços é novos clientes chegam ao hotel.

Liane ressalta que o valor cobrado para classificação é muito alto, apesar das vantagens e mudanças sentidas ate agora.

Como o hotel sempre seguiu as exigências da Embratur não foi muito difícil adequar a estrutura do mesmo às novas exigências de classificação, o hotel foi construído pensando para atender ao padrão de hospedes.

Como difiuldade durante o processo de classificação o hotel sentiu a resistência de seus funcionários frente às mudanças e quebras de paradigmas.

O Hotel Atlante Plaza conta com 231 apartamentos e suites com ar condicionado, frigobar, cofres individuais, voice mail, TV a cabo, apartamentos especiais para executivos, com duas linhas telefônicas, instalação para fax-modem e computador, tomadas estabilizadas, mesa de trabalho, cadeira giratória. O Hotel Atlante Plaza oferece uma estrutura de lazer com piscina e ainda sala de ginástica, sauna.. Na cobertura encontra-se o salão de beleza e sala de jogos.

O Hotel ica localizado à beira mar de Boa Viagem, perto do aeroporto Internacional Guararapes,apenas a $5 \mathrm{Km}$ e a 15 minutos do centro.

O Restaurante Mirage trabalha com cozinha internacional. Outra opção é o Restaurante Brasserie, localizado no Lobby do hotel, são servidos café da manhã e almoço alem da feijoada aos sábados ou grelhados aos domingos. Existe também o Night an Day, piano bar 
Com o objetivo de facilitar a temporada dos clientes, o Atlante Plaza disponibiliza serviços exclusivos: check-in antecipado TAM, agências de viagens, pré check-in e express checkout, transfer aeroporto/hotel/aeroporto, e ainda locadora de veículos e loja.

No Lobby do hotel, mais facilidades à disposição: Business Center aberto 24 horas, com sala totalmente equipada com computador, fax, impressora, acesso à Internet, TV e vídeo, o excelente atendimento completam a estrutura para seus negócios.

São 07 salões moduláveis, com capacidade para até 1.500 pessoas, totalmente equipados para reuniões, banquetes, seminários, feiras, congressos. Disponibilizamos toda a estrutura de apoio para a realização do seu evento: sala de reunião, assessoria para contratação de serviços especiais, salões com tomadas para 110 ou 220 Volts, tarifação automática de ligações telefônicas, antena parabólica para teleconferência.

3.2 Fiesta Bahia - 5 Estrelas 
O Fiesta conta com a certificação Iso 9002 alem da classificação da Embratur. O hotel conta com uma ótima infra estrutura para eventos, um centro de convenções com capacidade para até 3295 pessoas simultaneamente, é um dos mais completos e sofisticados da hotelaria brasileira.

O Fiesta tem como diferencial um andar exclusivamente feminino, todo o andar é equipado e decorado com utensílios de necessidade feminina.

O cartão Prestige é outro diferencial. Hospedes que tiverem oito ou mais diárias tem alguns privilégios como: check in e check out personalizado, acesso liberado a sauna, late check out ate as $16 \mathrm{~h}$, descontos de ate $20 \%$ em locadoras de automóveis, restaurantes e agencias de passeios, jornal A Gazeta diariamente, acesso liberado ao Business Center e Internet e cesta de frutas no primeiro dia de hospedagem.

O restaurante El Tenedor trabalha coma cozinha internacional.

Os apartamentos contam com ar condicionado,linha telefônica direta, pontos para micro e fax, tv com canais via satélite, frigobar e cofre.

O Fiesta conta ainda com salão de beleza,aluguel de carros e passeios, coffee shop, room service 24 horas e atendimento bilíngüe.

São 2 psicinas, jardim tropical, health club com sala de ginstica, sala de estar com home theather e mesa de jogos, massagem, ducha escocesa, sauna e quadra de tênis. 
Com uma magnífica localização frente ao mar, permitindo vista mar e cidade a todos os quartos, o Pestana Bahia Hotel oferece o enquadramento perfeito para uma estadia de lazer ou conferências, tendo toda a flexibilidade e as maiores e mais modernas facilidades daquela área.

Salvador da Bahia é um dos pontos culturais do Brasil que possui uma cultura afro-brasileira o hotel conta com 433 confortáveis apartamentos, incluíndo 42 Suites e 03 Suites Presidenciais.

Todos os apartamentos e suítes possuem vista mar e estão equipados com:

- Ar condicionado

- TV a cabo

- Minibar

- Rádio

- Cofre

- 02 linhas telefônicas

- Ligação à internet banda larga

- Apartamentos para deficiêntes física

Localizado no $23^{\circ}$ andar, funciona das 06h30 às $10 \mathrm{~h} 00$ o Lounge a Clarineta para café da manhã do Programa Executivo. Aos Domingos, das 12h00 às 16h00, é servido um Brunch.

São servidos café da manhã (06h30 - 10h30), almoço (12h00 - 15h00) e jantar (19h00 24h00). O cardápio do jantar é composto por especialidades da gastronomia portuguesa e baiana.

Centro de Convenções com 2.535 m² $^{2}$ de área de eventos, com capacidade para até 2.400 pessoas.

- 25 salas com capacidade até 600 pessoas em estilo auditório.

- Centro de Exposições Jorge Amado com 758m².

- Completo Business Center

- Profissionais especializados

- Total infra-estrutura de equipamentos audio-visuais 
- 2 piscinas panorâmicas

- Saunas

- Fitness Center

- Serviço de massagem

- Animação

- Pestana Kids

- Room Service 24 horas

- Cabeleireiro

- Lojas (joalheria, boutiques)

- Agência de viagens

- Loja TAM Linhas Aéreas

- Serviço de praia

- Traslado aeroporto/hotel/aeroporto

- Serviço de baby sitter

- Programa Executivo

- Completo Business Center

- Guest Relations

- Passeios turísticos e outras atividades podem ser solicitadas ao Concierge 


\subsection{Hotel Brisa Mar - São Luiz - 4 Estrelas}

Localizado em São Luiz o hotel recebeu a Classificação de hotel 4 estrelas.

As instalações oferecem restaurante, piscina, átrio para eventos e apartamentos superiores e standarts com ar condicionado, frigobar e tv a cabo.

\subsection{Hotel Alta Reggia Curitiba - 4 Estrelas}

São 84 unidades habitacionais com ar condicionado, calefação, frigobar, tv, cofre, sacada e ponto para Internet.

O hotel oferece ainda restaurante, lobby bar, piscina, sala de ginástica, garagem, room service, lavanderia, área de eventos para ate 180 pessoas, business center e serviços de emergência medica gratuita, aluguel de carros e passeios turisticos, floricultura, traslados e pacotes de núpcias.

\subsection{Hotel Bourbon Curitiba - Cinco Estrelas}

São 16andares com 147 apartmanetos e 28 suites divididas em categorias superior, máster, classic, diplomata, nobre e presidencial com diferenciais como banheira com hidromassagem, piscina, sauna, 2 pavimentos e camas de $2 \mathrm{~m}$ x $2 \mathrm{~m}$.

Andares para não fumantes, centro de convenções para ate 1000 pessoas, business center totalmente equipado, guest relation bilíngüe, baby sitter, salão de beleza, manobrista, fitness center, piscina aquecida, sauna seca e a vapor, ducha circular e escocesa e massagem.

\subsection{Ocean Palace - Natal - 5 Estrelas}

Hotel com 213 unidades habitacionais dividas em categorias como: suíte presidencial, suíte executiva, suíte Junior, apartamentos superiores luxo, apartamentos luxo e standarts. Com um diferencial encantador de tv's tela $100 \%$ plana.

O Hotel dispõem de restaurantes, bares e um parque aquático com piscinas e deck sobre o mar da praia de Ponta Negra.

O hotel oferece serviços de farmácia, salão de beleza, lazer para crianças com o Kids Ocean alem de serviços como massagem, fitness, sauna, campo de futebol, bicicletario, quadra de squash, futebol de areia e voley de praia. 
O hotel dispõem de 285 unidades habitacionais, 2 restaurantes, 2 bares alem do bar da psicina.

Possui sala para reuniões, salão de jogos, animação, jacuzzi, banho turco, massagem, quadra de tênis, agencia de viagens, cabelereiro, business center, clube criança e ginásio.

\subsection{Rede Luxor}

A rede luxor conta com 8 hoteis dos quais 4 estão classificados. 
Questionário para Monografia em Gestão da Hospitalidade da Universidade de Brasília UNB com o tema "Classificação dos Meios de Hospedagem : validade para os empreendimentos Hoteleiros”.

Solicitamos que responda as questões abaixo relacionadas.

Informamos que todas as respostas serão utilizadas apenas para a monografia formatadas como texto, que servirão como fonte para a conclusão do trabalho.

Desde já agradeço a atenção dispensada considerando a distancia e dificuldade em responder questões a um aluno não presente.

Obrigada,

Atenciosamente,

Débora Candeia

1. A classificação atribui real importância aos aspectos relacionados à prestação de serviços? Se sim quais? Se não, o que deveria ter sido mencionado?

- Sim, pois exige o máximo de conforto , qualidade e segurança, para hóspedes e funcionários;

2. A classificação atribuiu importância necessária aos aspectos relacionados a instalações?

- Sim, as normas para a estrutura do hotel é bem rígida bem como os artigos nas unidades habitacionais.

3. A ocupação do hotel mudou significativamente após a classificação? Dê exemplos.;

- Ainda não, isso será medido a longo prazo, apesar dos hóspedes term sentido grande diferença.

4. Os hóspedes notaram diferenças e gostaram ou não?

- Sim, sentem as mudanças de infra estrutura e serviços.

5. Comercialmente o hotel se tornou mais rentável?

- O hotel tem tirado grande proveito da classificação na mídia, pois ela é sinônimo de status, mas a rentabilidade dar-se-a a longo prazo.

6. O valor cobrado pela classificação é adequado? 
- O valor é alto, mas não nos cabe avaliar isso no momento.

7. Que principais mudanças/adequações o hotel teve que realizar a nível de instalações e serviços?

- Não grandes mudanças pois já havia sido construído encima dos requisitos da classificação antiga.

8. Como a classificação tem sido usada pelo hotel a nível de marketing e divulgação?

- Já foi respondido acima. Mas os hospedes tem indicado o hotel a outras pessoas que se tornam nossos hóspedes.

9. Internacionalmente o hotel tem sido referência?

- O hotel já era referência internacional antes da classificação.

10. Quais as maiores dificuldades sentidas pelo hotel e sua equipe no período de classificação.

- As dificuldades foram a nível de pessoal, muito resistente a mudanças e quebra de velhos paradigmas. 
5. Caso Rede Atlântica de Hotéis - Atlântica Hotels Internacional - Hotel Comfort Suítes Brasilia

O hotel Comfort Suítes Brasília pertence a uma rede chamada Atlantica International.

É uma administradora brasileira que administra marcas internacionais.

Conta com 42 hoteis no Brasil e mais de 7000 no mundoe possui varias categorias, de hotel luxo superior à econômico, nenhum classificado pela Embratur.

A diretora da Atlantica diz que a classificação não influencia diretamente nas negociações e serviços da rede, pois a cadeia conta com uma padronização própria reconhecida em todo o mundo de serviços e infra estrutura. E que por ser uma cadeia americana as classificações brasileiras não condizem com a filosofia da rede.

Com sede em São Paulo a Atlantica Hotels International é a primeira administradora hoteleira multimarcas da América do Sul, e a única multinacional hoteleira a focar especialmente a indústria de hospitalidade da Região, com ênfase no Brasil. A empresa tem alianças exclusivas com algumas das maiores redes hoteleiras do mundo: Choice Hotels International (Sleep Inn, Comfort, Comfort Suites, Quality e Clarion), Carlson Companies (Radisson Hotels \& Resorts) e Starwood (Four Points by Sheraton).

Atualmente, a Atlantica Hotels possui mais de 83 projetos assinados - 41 já em operação que totalizam, em conjunto com seus parceiros, investimentos de mais de US\$ 800 milhões. A Atlantica Hotels oferece aos seus clientes hotéis de diferentes estilos, de padrão econômico ao luxo, em localizações diversificadas. Todos os hotéis fazem parte do programa "100\% Satisfação Garantida" e contam com serviços de qualidade, preços acessíveis e apartamentos adaptados aos viajantes de negócios e lazer.

\section{ATLANTICA HOTELS INTERNATIONAL - TIMELINE}

1996 A Barrington Hotels \& Resorts BIH LTD (que administrava na época 68 hotéis na Europa), por meio de sua subsidiária Choice Hotels Empreendimentos do Brasil, inicia operações no país somente como franqueador das bandeiras Choice (Sleep Inn, Comfort e Quality).

1998 Brasil: Choice Atlantica International - franchising e administração de bandeiras da rede Choice Hotels International.

Dezembro - Quality Suites Garden

Setembro - Comfort Hotel Paulista 


\author{
Argentina: \\ Choice del Plata \\ Clarion Aspens - Buenos Aires \\ Comfort Aspens - Buenos Aires \\ Chile: \\ Choice del Pacífico \\ Quality Hotel Bonaparte - Santiago
}

Total de empreendimentos no Brasil: 02

1999 Julho - Abertura Sleep Inn Galeria - Campinas

Total de empreendimentos no Brasil: 03

2000 Janeiro - Sleep Inn Ribeirão Preto

Setembro - Quality Suites Metrópolis (SP)

Outubro - Comfort Hotel Ilha do Leite (Recife)

Total de empreendimentos no Brasil: 06

2001 Março - Quality Hotel Fortaleza

Maio - Mudança da razão social para Atlantica Hotels International

A adoção do novo nome teve como objetivo viabilizar a expansão da empresa para o segmento quatro e cinco estrelas, o que a tornou a maior empresa independente de administração hoteleira da América do Sul, com o estabelecimento de acordos preferenciais multimarcas.

Maio - Parceria com a master franqueadora Starwood Hotels; abertura do Four Points Sheraton Curitiba

Maio - Quality Resort Lins

Junho - Comfort Suites Oscar Freire (SP)

Agosto - Comfort Hotel Ribeirão Preto

Setembro - Comfort Suites Alphaville Campinas e Sleep Inn Varginha (MG)

Novembro - Quality Suites Imperial Hall (SP)

Dezembro - Parceria com a Carlson Companies - abertura do Radisson Faria Lima, Comfort Hotel Fortaleza e - Joint Venture com Qualitá Hotelaria criação da Atlantica Centro-Oeste, abertura do Quality Hotel \& Suites Lakeside (Brasília), Quality Suites Vila Velha (ES) e Comfort Suites Belvedere (Nova Lima - MG)

Dezembro - Joint Venture com Qualitá Hotelaria - criação da Atlantica Hotels Centro-Oeste

Dezembro - Comfort Hotel Fortaleza; Quality Hotel \& Suites Lakeside (Brasília); Quality Suites Vila Velha (ES); Comfort Suites Belvedere (Nova Lima-MG)

Total de empreendimentos no Brasil: 19

2002 Janeiro - Metropolitan Flat (Brasília) e Bonaparte Hotel (Brasília) Fevereiro - Criação dos primeiros quatro CEOs - Centros Estratégicos Operacionais Os CEOs são compostos por um diretor de operações, um controller e um gerente de vendas, responsáveis por um número determinado de empreendimentos, divididos por regiões geográficas. 
Criação dos primeiros quatro CEO's - Centros Estratégicos Operacionais Março - Reformulação da estrutura de vendas; criação de gerências regionais de vendas

Março - Quality Suites Bento Gonçalves (RS)

Abril - Quality Hotel Boa Viagem (Recife); Crystal Place Hotel Residence

(Goiânia); Comfort Suites Flamboyant (Goiânia)

Maio - Quality Suites Long Stay Bela Cintra (SP); Comfort Hotel Guarulhos

Maio - Lançamento das campanhas "Cliente nas Nuvens" e "Unidas Rent a Car"

A campanha 'Cliente nas Nuvens' foi estabelecida por meio da parceria com a companhia aérea Rio Sul. Válida para os empreendimentos em fase de abertura, a promoção dita que, a cada sete noites (acumuladas e que não precisam ser consecutivas), o hóspede ganha uma passagem aérea da Rio Sul, para qualquer destino operado pela companhia aérea.

Na campanha com a Unidas Rent a Car a cada sete noites (acumuladas e não necessariamente consecutivas) em qualquer dos empreendimentos da rede, o hóspede ganha uma noite de hospedagem grátis no mesmo empreendimento e uma diária de um carro da Unidas Rent a Car.

Junho - Quality Hotel Afonso Pena (Belo Horizonte)

Julho - Lançamento do Cartão Preferencial Atlantica Gold

Iniciativa inédita no mercado hoteleiro o Cartão Preferencial Atlantica Gold é um benefício exclusivo para seus investidores. $\mathrm{O}$ instrumento permite um substancial desconto nas diárias em quaisquer empreendimentos da rede no Brasil, válido também para os seus familiares.

Agosto - Conversão Bonaparte Hotel para Clarion Suites Bonaparte

Setembro - Quality Suites Long Stay Alvorada (SP)

Outubro - Comfort Hotel Vitória Praia (Vitória-ES)

Novembro - Comfort Hotel Itu

Dezembro - Lançamento da parceria com programa de milhagem Smiles (Varig)

A parceria converte em milhas gastos com hospedagem em quaisquer dos empreendimentos administrados pela Atlantica Hotels no Brasil. A promoção premia em uma mesma reserva de hospedagem hóspedes, agentes de viagens e secretárias (coordenadores de viagens).

Total de empreendimentos no Brasil: 31

2003 Janeiro- Quality Jardins (SP)

Foi eleito a rede preferida dos leitores da revista Business Travel

Fevereiro - Pier Vitória Hotel (Vitória-ES)

Abertura do escritório de Vendas (HD - Hotel Direto) no Rio de Janeiro Criação do cargo de VP de Recursos Humanos - promoção da diretora de RH, Dináurea Cheffins

MarçoQuality Ibirapuera (SP) Residencial Tower Ibirapuera

Reestruturação dos canais de Vendas - reformulação da Central de Reservas Abril - Comfort Suites Londrina (PR)

Estabelecimento do Andar Feminino em toda a rede (bandeiras Quality, Clarion, Four Points By Sheraton e Radisson)

Início da promoção '100 Milhas por Dia', em parceria com Smiles

Premiação com selo 'Hospitality Gold Award', da rede Choice International aos empreendimentos: Comfort Hotel Ribeirão Preto (Ribeirão Preto-SP), Comfort Suites Campinas (Campinas-SP) e Quality Resort \& Convention Center (Lins-SP) 
Maio - Quality Suites Congonhas (SP)

Quality Faria Lima (SP)

Introdução do Programa "Selo Azul" - para garantir o padrão de qualidade internacional nos serviços e instalações em toda a rede

Comfort Suites Campinas (Campinas-SP) é nomeado um dos cinco finalistas

para o prêmio "2003 Hotel of The Year", promovido pela rede Choice Hotels

International

Junho - Quality Suites Santo André (ABC-SP)

Realização da $4^{\mathrm{a}}$ Conferência Anual da Atlantica Hotels no Quality

Congonhas

Criação do departamento de Serviços de Suporte Hoteleiro

Julho - Quality Moema (SP)

Clarion Hotel Berrini (SP)

Victory Business (Juiz de Fora-MG)

Agosto - Comfort Suites Alphaville (Barueri-SP)

Comfort Suites Brasília (DF)

Comfort Hotel Vila Mariana (SP)

Previsão de 65 hotéis em operação

Bandeiras da Rede Atlantica

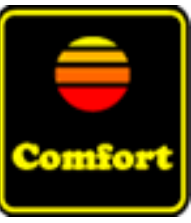

Econômico

\section{Comfort Inn \& Hotels}

Empreendimento com serviços essenciais e apartamentos nos moldes dos padrões definidos para a marca - no mínimo 100 apartamentos, com 24 $\mathrm{m}^{2}$ cada, Comfort é a bandeira de maior crescimento nos Estados Unidos, sendo também a maior das sete marcas franqueadas pela Choice Hotels International. Apesar das novas construções contribuírem significativamente para o crescimento da marca, os Comfort também aceitam a conversão de empreendimentos já existentes. Atualmente, 1.805 Comfort encontram-se em operação e 311 em desenvolvimento, representando um total de 163.224 apartamentos pelo mundo, que oferecem $100 \%$ de satisfação garantida ao cliente, café da manhã e 
jornais de cortesia.

\section{Comfort Suites}

Com cerca de 1.800 produtos em operação e mais de 300 em desenvolvimento, em todo o mundo - totalizando aproximadamente 163.224 apartamentos -, Comfort Suites é a marca de maior crescimento no mercado norte-americano. Seus empreendimentos possuem suítes com áreas divididas para quarto e sala, e com amplo espaço para garantir o conforto de seus hóspedes. Os empreendimentos contam com piscina, área de eventos, café da manhã incluso na diária, 60\% de apartamentos destinados a não fumantes, jornal como cortesia, além dos programas de qualidade 100\% Satisfação Garantida e Service One.

\section{Quality Resorts, Hotels \& Suites}

Considerada como a marca de preços intermediários e serviços completos do grupo, os Quality são reconhecidos internacionalmente há mais de 50 anos por seus serviços de hospedagem de qualidade superior. A marca diferencia-se das bandeiras Comfort e do Sleep Inn pela oferta de uma ampla gama de serviços, incluindo restaurantes, áreas para descanso e instalações para a realização de reuniões e banquetes. Atualmente, 730 Quality encontram-se em operação e 115, em desenvolvimento, representando um total de 91.408 apartamentos pelo mundo.

\section{Clarion Hotels \& Resorts}

A marca Clarion oferece todos os serviços dos Inns, Hotéis, Suites e Resorts, proporcionando ao viajante uma diversidade de estilos de empreendimentos e de localizações. Seus serviços e amenidades são feitos sob medida para hóspedes exigentes, quando em viagem de negócios ou somente para relaxar em um resort. Atualmente, 144 unidades Clarion encontram-se em operação e 33 em desenvolvimento, 
representando um total de 27.744 apartamentos em todo o mundo.

\section{Four Points by Sheraton Hotel}

Presente em 12 países, com um total de 144 empreendimentos em operação, a marca Four Points by Sheraton Hotel pertence à master franqueadora Starwood Hotels (atual detentora das marcas Sheraton, Four Points, Westin, Saint Regis, W Hotels) oferecendo empreendimentos de alto padrão para viajantes de negócios e lazer. Em maio de 2001, a Atlantica Hotels International estabeleceu um acordo comercial com o grupo Starwood para administrar o primeiro empreendimento com a bandeira Four Points by Sheraton Hotel no Brasil, localizado na cidade de Curitiba (PR).

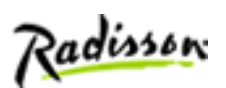

Luxo

\section{Radisson}

Presente em 58 países, com um total de 420 empreendimentos em operação, a marca Radisson é líder mundial no segmento de hospedagem de alto padrão e possui tradição como uma bandeira que garante a satisfação de seus hóspedes por meio de seu comprometimento em fornecer serviços personalizados e através de programas de fidelidade como "Look to Book" e "Gold Rewards". A Atlantica Hotels International desenvolve uma parceria estratégica com o grupo Carlson atual detentor das marcas Regent International Hotels, Radisson Hotels and Resorts, Country Inn \& Suites, Park Plaza e Park Inn e outras empresas relacionadas ao segmento de turismo como Carlson Wagonlit Travel, Carlson Marketing Group e Radisson Seven Seas Cruises (que conta com seis navios de cruzeiros espalhados pelo mundo).

Outro diferencial da marca é o fato de possuir o suporte da Carlson Companies, Inc. - rede de empresas relacionadas ao segmento de turismo, que inclui Carlson Wagonlit Travel e Carlson Marketing Group -, conectada com mais de 455.000 agentes de turismo por meio de um sistema tecnológico de última geração. 
